\title{
UMJETNOST KAO PROPAGANDA: IVAN MEŠTROVIĆ, SUKOBLJENE PARALELNE KULTURNE POLITIKE I VELIKI RAT
}

\author{
Filip ŠIMETIN ŠEGVIĆ \\ Filozofski fakultet, Odsjek za povijest \\ Sveučilište u Zagrebu \\ Zagreb, Hrvatska
}

\author{
UDK: 94(100)21914/1918“: 73 Meštrović, I. \\ DOI: $10.21857 / \mathrm{y} 54 \mathrm{jofk} 7 \mathrm{dm}$ \\ Izvorni znanstveni rad \\ Prihvaćeno: 9. ožujka 2021.
}

U radu se analiziraju paralelne kulturne politike Jugoslavenskog odbora, odnosno Ivana Meštrovića u Velikoj Britaniji (1915. - 1918.), i pokušaji da se u Hrvatskoj tijekom trajanja Velikog rata mobilizira osobito civilno stanovništvo pomoću propagandnih ratnih izložbi. Pritom se objašnjava geneza raskola među umjetničkim krugovima i ideološka matrica onih koji su pristajali uz kulturno jugoslavenstvo, odnosno onih koji su pokušavali djelovati u sklopu Glavnog stana ratne štampe kao središnjeg mjesta okupljanja intelektualaca i umjetnika iz čitave Habsburške Monarhije.

Ključne riječi: Veliki rat, propaganda, kultura, umjetnost, izložbe, intelektualci, Ivan Meštrović, ideologija.

\section{UVOD}

Čak i prije početka Velikog rata 1914. godine u Habsburškoj Monarhiji vode se najrazličitiji sukobi na području kulture: od velikih intelektualnih debata oko uloge umjetnosti i kulture i društvu, prijepora o estetici u umjetnosti, rasprava o dekadenciji do politički nabijenih razilaženja i čitanja umjetnosti kao, takorečeno, „produžene ruke politike“. ${ }^{1}$ Stanje kulture i atmosfera u hrvatskim intelektualnim krugovima u razdoblju oko 1900. godine obilježeni su prije svega izvanjskim događajima i podražajima. Na političkoj sceni to je jedno od prijelaznih razdoblja, kada će određene političke razine lojalnosti prema Beču ili Budimpešti biti redefinirane u okvirima pravaških i unionističkih strujanja, ali će i koncepcije poput jugoslavizma doživjeti smjenu generacija, odnosno intelektualno regeneriranje ideja koje će oko 1900. godine integrirati u određenoj

1 I dalje su standardna djela za opći pregled kulturne i intelektualne povijesti Habsburške Monarhije ona W. M. Johnstona, Carla Schorskea i Pétera Hanáka. Vidjeti: William M. Johnston, Austrijski duh, Zagreb, 1993.; Carl E. Schorske, Beč krajem stoljeća, Zagreb, 1997.; Péter HanÁk, The Garden and the Workshop, New York, 1998. Za Hrvatsku u to doba vidi primjerice: Fin de siècle Zagreb-Beč, ur. Damir Barbarić, Zagreb, 1997.; Nikola BATušIć, Zoran KRAVAR, Viktor ŽMEGAČ, Književni protusvjetovi, Zagreb, 2001. 
mjeri i sve spomenute prijepore oko kulture. ${ }^{2}$ Mlađe generacije umjetnika i intelektualaca, najčešće karakterizirane upravo kao „mladi“, pokušavaju pronaći novu ili drugačiju formulu u odnosu na njihovo društveno djelovanje, za što poticaje dobivaju u slavenskim (Prag) ili drugim središtima Monarhije (Beč, Graz).

Konkretno, u Hrvatskoj i Slavoniji zatičemo oko 1900. godine jedan sustav kulture i kulturnog razvoja kakav je stvoren pod banom Károlyjem KhuenHéderváryjem (1883. - 1903.), ponajviše uz djelatnost Izidora Kršnjavog kao predstojnika Odjela za bogoštovlje i nastavu. U financijskom smislu taj je sustav oko 1900. već nekoliko godina u trajnoj krizi, jer se oslanjao na stalna ulaganja nužna $u$ željenom procesu stvaranja umjetničkih kolonija i institucionalne mreže koja je pod okriljem Zemaljske vlade i Odjela za bogoštovlje i nastavu osobito od Zagreba činila glavno hrvatsko kulturno središte. U vrijeme KhuenHéderváryja kultura je prije svega za bansku vlast značila sredstvo propagande kojim se ostvaruju politički ciljevi Beča, ali i osobni ciljevi bana. ${ }^{3}$ Takvu strategiju povremeno primjenjuje i ban Tomašić (1910. - 1912.), bliski suradnik KhuenHéderváryja (tada na mjestu ugarskog ministra-predsjednika), želeći svoju uspješnost podcrtati ostvarenim kulturnim projektima. No za pojedince poput Kršnjavog kulturna politika nije bila samo strategija ni opća tendencija da se potakne institucionalni razvoj i uređenje poslova. Pojedinci koji su to područje vidjeli kao svoj resor, počevši od Strossmayera pa do vladinih predstojnika, Kršnjavog, Armina Pavića ili Milana Amruša i Milana Rojca, nastojali su postići što veću kontrolu nad institucijama i pojedincima kako bi se provodila određena kulturna i politička strategija, sustav, kako bi se postavila jasnija mjerila i kriteriji: utoliko je njihov intelektualno-znanstveni rad sukladan s političkim djelovanjem.

Kada oko 1900. godine dolazi do rasprava ili sukoba između „mladih“ i „starih“, borba se uvelike odnosi i na omjer kontrole koji Zemaljska vlada i Odjel za bogoštovlje i nastavu egzerciraju nad pojedinim institucijama, predstavnicima institucija ili pojedincima. Secesionisti i modernisti pokušat će uvesti neku vrstu paralelnih institucija i organa: od časopisa koji su modernistički orijentirani prema bečkim i europskim uzorima (Život, Mladost koja izlazi u Beču, Hrvatska misao koja izlazi u Pragu), do konkretnih organiziranih institucija kao što je Društvo hrvatskih umjetnika i njemu pripadajući Klub hrvatskih književnika

2 Usp. Mirjana Gross, Nacionalnointegracijske ideologije u Hrvata od kraja ilirizma do stvaranja Jugoslavije, u: Društveni razvoj u Hrvatskoj od 16. do početka 20. stoljeća, ur. Mirjana Gross, Zagreb, 1981., 283 - 306, ovdje 286 - 297.

3 O tome u: Filip ŠIMETIn ŠEgvić, Patriotizam i bunt: Franjo Josip I. u Zagrebu, Zagreb, 2014., 14 - 31. 
(1897.). U drugoj fazi stvara se, na temeljima ilirizma i Strossmayerove politike u drugoj polovici 19. stoljeća, novo usmjerenje kulturne i političke ideologije preko raznih časopisa Omladine (npr. Hrvatski djak koji izlazi u Zagrebu pa potom Pragu, bosanskohercegovačka omladina oko Zore, slovenska oko Vala). Heterogenost stanovništva urbanih središta Habsburške Monarhije pogodovala je razvijanju različitih intelektualnih strujanja i inačica tih strujanja u lokalnom kontekstu, stvarajući mreže manje ili više povezanih skupina intelektualaca i ideja koje su se transferirale s područja središta na rubna područja - Hrvatsku i Slavoniju odnosno Dalmaciju i Istru, ali koje su se sukladno i u tim središtima dalje razvijale. Pregršt različitih motivacija i razloga, počevši od osobnih pa sve do strukturalnih, navodio je mlade generacije intelektualaca da se pokušavaju organizirati putem novih, modernijih društava i institucija, a da su pritom u političkom smislu još bili relativno bliski ranijim usmjerenjima. U Dalmaciji promjene koje donosi politika novog kursa nastavljaju se na ranije postavljene temelje onih umjetnika i intelektualaca koji su ondje pronašli mirnije utočište $u$ odnosu na dominaciju sustava kulture Kršnjavog i Khuena. U tome valja tražiti i korijene uspjeha Prve dalmatinske izložbe u drugoj polovici 1908. godine. ${ }^{4}$

\section{MEŠTROVIĆ KAO SPRITIUS MOVENS „JUGOSLAVENSKE“ KULTURNE POLITIKE}

Split, suprotno od „činovničkog“ Zadra, ${ }^{5}$ lakše afirmira dio tih modernistički orijentiranih umjetnika i intelektualaca djelatnih i u Zagrebu. U dalmatinskom kontekstu obilježenom međunacionalnim sukobima, ali udaljenom od kulturne politike Zemaljske vlade, skupina hrvatskih umjetnika stupa na scenu putem uspješnih izložbi i kulturnih manifestacija. To osobito postaje vidljivo kroz rad Društva Medulić. Društvo umjetnika Medulić osnovano je 1908. godine na Prvoj dalmatinskoj umjetničkoj izložbi u Splitu. ${ }^{6}$ Ono je isprva formalno pod vodstvom slikara Vlahe Bukovca, ali ga ustvari vode mladi Emanuel Vidović i Ivan Meštrović. Jedna od prednosti Društva Medulić bila je što je u splitskom

4 Usp. Marko Trogrlić, Nevio ŠEtić, Dalmacija i Istra u 19. stoljeću, Zagreb, 1915., 93 - 94; Sandi BULımb Ašıć, Iso Kršnjavi i Društvo hrvatskih umjetnika „Medulić“, u: Zbornik radova znanstvenog skupa Iso Kršnjavi - veliki utemeljitelj, ur. Ivana Mance, Zlatko Matijević, Zagreb, 2015., 334 - 352.

5 Ante Bralić, Zadarski fin-de siècle - Političke i društvene prilike u Zadru i Dalmaciji uoči Prvoga svjetskog rata, Časopis za suvremenu povijest, sv. 39, Zagreb, 2007., 731 - 775.

6 Novija studija o nastanku i radu Društva Medulić Sandi Bulimbašić donosi nove i do sada nepoznate podatke. Vidjeti: Sandi Bulimbašić, Društvo hrvatskih umjetnika "Medulić" (1908. 1919.): umjetnost i politika, Zagreb, 2016. 
kontekstu moglo djelovati i razvijati krug suradnika podalje od utjecaja Izidora Kršnjavog. K tomu je i u idejnom smislu pogodan bio dalmatinski kontekst između talijanskih i austrijskih utjecaja, ali i jugoslavenskih strujanja. To je isprva značilo široku intelektualnu platformu koja je objedinjavala umjetnike i druge intelektualce različitih provenijencija i usmjerenja, od onih tradicionalnije orijentiranih i generacijski starijih pa sve do vrlo mladih modernista s čitavog hrvatskog područja, dakle ne samo Dalmacije. Izložbe društva bilježe prilične uspjehe i veću posjećenost negoli bilo koje ranije takve kulturne manifestacije, izuzev dakako prvog Hrvatskog salona koji je 1898. godine održan u Zagrebu. ${ }^{7}$

Za Društvo Medulić neizmjerno je važna pojava Ivana Meštrovića, koji je od skromnih početaka uspio u Beču tijekom studija i sudjelovanjem na važnim izložbama secesionista steći ime u središtu Monarhije, prije negoli je to mogao u Zagrebu ili Splitu. Ivan Meštrović je pak iz Dalmacije u Beč stigao podrškom bogatog industrijalca Alexandera Königa ${ }^{8}$ ali se također u početnim godinama morao oslanjati i na pomoć Kršnjavog koji je mogao doći do sredstava preko Društva umjetnosti ili mu ih je osobno davao. ${ }^{9}$ Hrvatski umjetnici oko 1900. godine još su uvijek uvelike ovisili o individualnim donacijama i mecenama iz krugova plemstva, bogatijeg građanstva i osobito privrednika i industrijalaca. Velik broj umjetnika toga vremena mogao se okupiti u Zagrebu samo uz pomoć stipendije Zemaljske vlade. Upravo je kulturna politika pod njezinim okriljem omogućila inicijalna iskustva u Austriji, Njemačkoj, Francuskoj i drugim zemljama. Tako Robert Auer svoje školovanje počinje u Zagrebu, ali posredstvom stipendija Zemaljske vlade i zalaganjem Izidora Kršnjavog odlazi dalje u Beč i München, Robert Frangeš-Mihanović odlazi u Beč i Pariz podrškom Odjela za bogoštovlje i nastavu te vladara Franje Josipa.

Meštrovićje mlađojgeneraciji intelektualaca i umjetnika zadavao takt, a njegov je modernizam najkasnije od 1904. godine povezan s kulturnim jugoslavenskim unitarizmom. Pritom treba imati na umu da su iskustva Meštrovića u Beču, Zagrebu i Splitu tomu postupno doprinosila. Upravo je pod ravnanjem Meštrovića došlo isprva do značajne izložbe 1910. u Zagrebu, nazvane simbolički „Nejunačkom vremenu u prkos“, koja je objedinjavala radove matrice Društva Medulić, ali i one srpske i slovenske provenijencije, najavljujući istovremeno

7 O široj kontekstualizaciji i samom događanju vidjeti: Petra Vugrinec, Hrvatski salon i bečka secesija: slikarstvo u Zagrebu i Beču oko 1900., u: Izazov moderne: Zagreb-Beč oko 1900. Slikarstvo, kiparstvo i arhitektura zagrebačke i bečke secesije, ur. Irena Kraševac, Petra Vugrinec, Zagreb, 2017., 57 - 124; Petar Prelog, Artikulacija moderniteta. Institucije, secesije, publika, u: Moderna umjetnost u Hrvatskoj 1898.-1975., ur. Ljiljana Kolešnik i Petar Prelog, Zagreb, 2012., 10 - 39.

8 Vidi: Irena KRAšEvaC, Ivan Meštrović i secesija. Beč-München-Prag 1900 - 1910, Zagreb, 2002., 18.

$9 \quad$ Usp. Maria MeŠT rović, Život i djelo Ivana Meštrovića, Zagreb, 2011., 41 - 43. 
tendenciju mladih umjetnika prema traženju takozvanog ,jugoslavenskog nacionalnog stila“, ali i razne druge utjecaje koji su i dalje bili jednako ukorijenjeni u devetnaestotstoljetnim idejama, kao i u svojevrsni „habsburški“ pristup nacionalnom pitanju. Ne treba stoga ni čuditi da je Meštrovića u Beču bilo inicijalno vrlo teško ocijeniti. Jedan članak o secesiji u bečkom tisku opisuje ga kao ,južnog Slavena iz Dalmacije“ koji je „proizvod nacionalne rustikalnosti“" koja „se u tehničkom smislu ispoljava u antici“. Inspiraciju je u „zemlji ratobornih Iliraca" pronašao u Dioklecijanovoj palači isprva i u venecijanskim utjecajima na Dalmaciju, a kasnije je preko Beča došao do Pariza gdje je u Louvreu proučavao antičke grčke kipove. ${ }^{10}$ Već iz ovog opisa jasno je kako se političnost nastojala zatomiti ili preusmjeriti, dok se Meštrovićeva pojava u Beču isprva vezala uz egzotičnost dalmatinskog podneblja i njezine povijesti. Međutim, većina umjetničkih društava oko 1900. poprima sve izraženije političke konotacije, iako treba ustvrditi da mnogi umjetnici izlažu na naizgled politički suprotstavljenim izložbama. Tako će u sklopu jugoslavenskih izložbi (manifestacije se održavaju od 1904.) koje su održavane uz sudjelovanja Društva hrvatskih umjetnika (ali ne i Društva umjetnosti), Saveza jugoslavenskih umjetnika Lada (odnosno hrvatskog odsjeka) i Društva Medulić, izlagati i Oton Iveković ili Robert FrangešMihanović, koji će se nakon 1914. naći na „protivničkoj“ strani Meštrovića, kao "genija Jugoslovenstva“ (M. Marjanović). ${ }^{11}$

\section{„KULTURNI RATOVI“ UMJETNIKA}

Do prvog većeg političko-kulturnog skandala u kojem sudjeluje društvo i koji je umjereno odjeknuo čitavom Austro-Ugarskom dolazi 1911. Kulturne su manifestacije već ranije, pred kraj 19. stoljeća, postajale poprište većih sukoba nacionalnih ideologija, skandala, pa čak i ekscesa ili ozbiljnih nereda. ${ }^{12}$ Početak „kulturnog rata“ pokrenuli su umjetnici oko Medulića, koji su se povodom Međunarodne izložbe umjetnosti i arheologije u Rimu odlučili na potez koji je do tada bio bez presedana. Upravo u tom kontekstu Meštrovićeva djela „Kosovski ciklus“ te prije svega model Vidovdanskog hrama - koje je pripremao u Beču

10 Sezession, Der Morgen. Wiener Montagblatt, br. 1, 24. 1. 1910.

11 O političkoj dimenziji jugoslavenskih izložbi vidi: Radina VUČETIĆ, Jugoslavenstvo u umjetnosti i kulturi - od zavodljivog mita do okrutne realnosti (Jugoslavenske izložbe 1904.-1940.), Časopis za suvremenu povijest, sv. 41/3, Zagreb, 2009., 701 - 714.

12 O tome u: Daniel L. Unows Ky, The Pomp and Politics of Patriotism: Imperial Celebrations in Habsburg Austria, 1848-1916, West Lafayette, 2005.; Marc Ferro, Resentment in History, Cambridge-Malden, 2010., 84-92. 
za izložbu secesije te potom izlagao u Zagrebu, dobivaju dodatnu ideološku dimenziju, jer dotad bezimena tijela dobivaju imena kosovskih junaka. ${ }^{13}$

Rimska izložba obilježavala je pola stoljeća talijanskog ujedinjenja, a u konceptualnom je smislu bila usmjerena kako na same Talijane tako i na širu europsku javnost, nastojeći slati razne poruke političkim saveznicima ili protivnicima. Budući da je prvo najavljeno nesudjelovanje Austro-Ugarske, daljnji je rasplet prouzrokovao velike političke i diplomatske poteškoće. Nakon što je već najavljeno nesudjelovanje, saznalo se da će Ugarska izlagati svoje eksponate i da su pripreme za sudjelovanje već u tijeku, ${ }^{14}$ da bi kompliciranim diplomatskim posredstvom u posljednji trenutak i Beč odlučio sudjelovati. ${ }^{15}$ Umjesto da izlažu u sklopu jednog austrougarskog paviljona, hrvatski su se umjetnici oko Meštrovića trudili isprva organizirati zasebni paviljon ili istaknuti zasebne narodnosti, što talijanski organizatori nisu dopustili. Meštrović je odbio i ponudu Milana Amruša da u sklopu ugarskog dijela, bez isticanja narodnosti, i bogatiju austrijsku ponudu izlaže kao „austrijski umjetnik“. Potom su se umjetnici Društva Medulić priključili izlagačima i paviljonu Kraljevine Srbije. ${ }^{16}$ Štoviše, Meštrović je čitavu koncepciju osmislio i nadzirao. Taj čin nije mogao biti shvaćen nego kao jasna politička provokacija ili poruka, što je izazvalo lanac poteza i protupoteza. U veljači svi listovi u Austro-Ugarskoj pišu o tome kako se u Srbiji šire vijesti da su Meštrovićeva djela iz Zagreba u Rim dopremljena na „barbarski“ način i da su oštećena namjerno. ${ }^{17}$ Zatim je pri određivanju prostora, dakako posve neslučajno, ispalo da se u zgradi iz austrijskog paviljona u ugarski može doći jedino preko - onoga Kraljevine Srbije. A bilanca sudjelovanja šalje još jasniju poruku koja nije promakla kritičkim notama austrijskog tiska; od

13 Moša Pijade, Ivan Meštrović i težnja za stilom u našoj umetnosti, Slobodna reč, sv. 40/41, Beograd, 1919., 1 - 16; Vinko SRHOJ, Ivan Meštrović i politika kao prostor ahistorijskog idealizma, Ars Adriatica, sv. 4, Zadar, 2014., 374 - 375; Aleksandar IgnJATović, Images of the Nation Foreseen: Ivan Meštrović's Vidovdan Temple and Primordial Yugoslavism, Slavic Review, sv. 73/4, Cambridge, 2014., 828 - 858 .

14 Prema memoarskim zapisima Ivana Meštrovića i navodima Marije Meštrović, Milan Amruš nudio je, nakon što je odbio sudjelovanje u sklopu austrijskog paviljona, da svoja djela izlaže u hrvatskoj sekciji ugarskog paviljona - što je Meštrović također odbio. M. MEšTrović, Život i djelo Ivana Meštrovića, Zagreb, 2011., 61.

15 O tome svjedoči diplomatska prepiska između austrougarskog konzulata u Rimu i Beča koju donosi austrijski povjesničar Heinrich Friedjung. Heinrich FrIEDJUNG, Geschichte in Gesprächen: 1904-1919, sv. 2, ur. Franz Adlgasser, Margret Friedrich, Wien, 1997., 258 - 260.

16 Ivan MešTrović, Uspomene na političke ljude i dogadaje, Zagreb, 1993., 19 - 20; Jozo KLJAKOvić, U suvremenom kaosu, Zagreb, 2011., 36 - 37; Maria MEŠTrović, Život i djelo Ivana Meštrovića, 60 - 61. Usp. S. Bulimbašıć, Iso Kršnjavi i Društvo hrvatskih umjetnika „Medulić, 347.

17 Zertrümmerte Skulpturwerke, Pester Lloyd, br. 41, 17. 2. 1911.; Barbarische Beschädigung eines Kunstwerkes, Das Vaterland, br. 52., 17. 2. 1911. 
23 izlagača u Srpskom paviljonu 14 ih je bilo Hrvata, a četvorica su bila Srbi s područja Austro-Ugarske. Ili, od ukupno 236 izloženih djela čak 203 dolazilo je s područja Austro-Ugarske. ${ }^{18}$ Skoro polovicu činila su Meštrovićeva djela, pa tisak primjećuje kako se iz austrijskog dijela koji zastupa Otto Wagner dolazi u srpski dio gdje „Austrija“ ponovno dominira preko Wagnerova „učenika“ Meštrovića, koji daje svoj biljeg modernističkim kiparstvom i gdje granično karikaturalno vladaju kontradikcije u usporedbi s „hiperkultiviranim radovima Engleza“. ${ }^{19}$ Dok su austrijski mediji temu izbjegavali, strani tisak osobito je pisao o Vidovdanskom hramu, odnosno modelu izgrađenom u drvu koji je u Rimu prvi put izložen, a potom 1914. u Veneciji i 1915. u Londonu; prema opisu talijanskog kipara Leonarda Bistolfija, hram je predstavljao intelektualnu esenciju jugoslavenstva, jer je ,jedinstvena misao sastavljena iz sviju misli jedne rase“ ${ }^{20}$

U Rimu je Meštrović nagrađen s prvom nagradom od 50.000 lira i zlatnom medaljom, ali još važnije, postao je pravi „mesija jugoslavenskog unitarizma“ i „prvi nacionalni“ (jugoslavenski) umjetnik. ${ }^{21}$ No to još nije bilo toliko očito u Austro-Ugarskoj, gdje se situacija nakon rimske izložbe postupno smirivala. ${ }^{22}$ Poznati redaktor i kritičar Ludwig Abels u feljtonu u Pester Lloydu krajem 1911. godine piše o atmosferi u Beču, gdje se umjetnička sloboda nedovoljno poštuje i gdje je teško uspjeti: upravo primjer Meštrovića kao genija koji je iz tih razloga bio prisiljen napustiti domovinu i okrenuti se nekom drugom ambijentu služi mu kao dobar primjer za opisivanje kulturne klime. ${ }^{23}$ Izidor Kršnjavi je pak ili bolje shvaćao ili je manje želio sakriti političke implikacije izložbe. Zbog toga je pokrenuo na noge tradicionalno Društvo umjetnosti, areal nad kojim je još imao izuzetno veliku kontrolu i koji se sve više sprječavao tendencijama mlađih umjetnika. U kulturno-političkom ratu koji je trebao buknuti - ali nije, istaknula se Kršnjavijeva ideja da organizira politički nabijenu izložbu „Vivat Habsburg“, koja bi poslala jasnu poruku jedinstvenog promonarhističkog sentimenta

18 Ivo BANAC, Nacionalno pitanje u Jugoslaviji, Zagreb, 1988., 196 - 197.

19 Italienische Kunstausstellungen, Neue Freie Presse, br. 16815, 16. 6. 1911.

20 s.a. [Milan Marjanović], Vidovdanski hram Ivana Meštrovića, Savremenik, sv. 6, Zagreb, $1919 ., 272$. Usp. M. MešTrović, Život i djelo Ivana Meštrovića, 63.

21 Kosta Strajnić, Ivan Meštrović, Beograd, 1919., 18; Ivo Banac, Nacionalno pitanje u Jugoslaviji, 197.

22 Vidi se to iz Meštrovićeva odnosa prema nekadašnjem meceni Karlu Wittgensteinu te iz nekih novinskih natpisa koji su pokušavali objasniti Meštrovićeve poteze. Irena KRAŠEvAC, Ivan Meštrović und sein Wiener Mäzen Karl Wittgenstein, u: Wechselwirkungen, sv. 7: Übergänge und Verflechtungen. Kulturelle Transfers in Europa, (ur. Gregor Kokorz i Helga Mitterbauer), Bern, 2004., 129 - 145, ovdje 142 - 143.

23 Kunstverständnis. Zum Beginn der neuen Ausstellungssaison, Pester Lloyd, br. 240, 10. 10. 1911. 
nasuprot rimskoj izložbi „dalmatinskog separatizma“. ${ }^{24} \mathrm{Ta}$ „protuizložba“, kako ju je sam Kršnjavi nazvao, nije uspjela u namjeri da bude proslava hrvatskog patriotizma i dinastičke lojalnosti. Plan da sudjelovanje na izložbi uvjetuje putem narudžbi umjetničkih djela koje je za dekoraciju Sveučilišne knjižnice dodjeljivala Zemaljska vlada nije uspio. ${ }^{25}$ A nije ni plan izložbe u Beču, centru Monarhije (u sklopu 50. obljetnice tamošnjeg umjetničkog društva), gdje bi nastupali hrvatski umjetnici s reprezentativnim djelima. Sve se svelo na znatno manje ambicioznu izložbu Društva umjetnosti u svibnju 1911., koja, unatoč dominantno postavljenoj Ivekovićevoj slici „Vivat Rex“ koja prikazuje Cetinski sabor iz 1527. godine ${ }^{26}$ i pripremljenom katalogu izložbe, nije ostvarila političke ciljeve. ${ }^{27}$ Sama je izložba objedinila ponovno respektabilne umjetnike, sudjelovali su Robert Auer, Kelement Menci Crnčić, Miroslav Kraljević, Robert Frangeš-Mihanović i drugi. Iako je upriličena paralelno s izložbom u Rimu te je izazvala određenu pozornost u Zagrebu i iako je ban Tomašić priliku iskoristio da se iskaže kao donator i mecena umjetnosti, ostala je bez pravog političkog efekta. Čak je i sam Kršnjavi u govoru na otvaranju više isticao značenje secesionizma, individualizma i partikularizma u umjetnosti (gdje su, za razliku od politike prema njemu poželjni), dotičući se namjerno i moderne Italije. ${ }^{28}$ Pritom je jasno postajalo da ono što je u suštini bilo početno shvaćano kao generacijsko, koncepcijsko i idejno razilaženje hrvatskih umjetnika sve je više postalo idejno-političko razilaženje. Meštrović je predvodio novi val promišljanja jugoslavenstva među umjetnicima, dok su oni koji su ostajali odani Kršnjavom ili režimu to činili iz različitih razloga, ali bez ozbiljne formulacije političkog programa u njihovoj umjetnosti.

\section{KULTURNI PROPAGANDNI RATOVI TIJEKOM VELIKOG RATA POD OKRILJEM SEKCIJE GLAVNOG STANA RATNE ŠTAMPE}

Prilikom izbijanja Prvog svjetskog rata kulturna propaganda na području Habsburške Monarhije isprva nije imala izrazitu težinu, odnosno nije se toliko obraćala pozornost tom aspektu, a ratna propaganda kao takva nije bila sustavno

24 S. Bulımbašić, Iso Kršnjavi i Društvo hrvatskih umjetnika „Medulić“, 349.

25 Iso KRŠNJAvi, Zapisci. Iza kulisa hrvatske politike, knj. 2, prir. Ivan Krtalić, Zagreb, 1986., 648, 685 -688 .

26 U literaturi toga vremena slika je nazivana „Vivat Rex“ ili „Vivat Habsburg“, kasnije i „Cetinjski sabor $1527 . “$

27 Ljubo Babić bilježi izložbu na kojoj je dominirala Ivekovićeva slika kao manifestaciju koja je „imala biti glavni ustuk nastupu hrvatskih umjetnika na Rimskoj izložbi (...)“. Ljubo BABIĆ, Umjetnost kod Hrvata u XIX. stoljeću, Zagreb, 1934., 116. Usp. Olga MARUšEvs KI, Društvo umjetnosti 1868.1879.-1941., Zagreb, 2004., 291 - 292. 
organizirana. Razni su književnici, pjesnici, slikari, kipari i drugi intelektualci ipak angažirani u proizvodnji propagandnih letaka, ratne poezije, plakata itd. Inteligencija je na početku rata prije svega korištena u svrhe bilježenja ratnih događanja i zapisivanja prve (propagandističke) povijesti zbivanja. ${ }^{29}$ Osim toga su fotografije s bojišta pomoću „Svjetloslikarskog odjela“ slane u sve hrvatske novinske redakcije, primjerice Ilustrovani list ili Dom i sviet. Propagandni dio rijetko je međutim nadilazio uobičajene moralističke poruke koje su, kako povjesničar Steffen Bruendel pokazuje na primjeru njemačke propagande, „počivale na povezivanju dobre savjesti i određene naivnosti“" ${ }^{30}$ Austrijski književnici koji su dugoročno predstavljali uzore hrvatskim modernistima, primjerice Hermann Bahr, Hugo von Hofmannsthal i Robert Müller, tijekom rata razvijali su svoj "nacionalistički kozmopolitizam“ usmjeren na Srednju Europu, Njemačku i Austriju, o čijem se identitetu sada pojačano razmišljalo. ${ }^{31}$

Hrvatski intelektualci i umjetnici ${ }^{32}$ našli su se uglavnom okupljeni oko novinskih agencija ili na bojištu, u sklopu sekcija Glavnog stana ratne štampe (k. u. k. Kriegspressequartier, KPQ) kao podsekcije Vrhovnog zapovjedništva vojske. Nazivan i „umjetničko-književnička fronta“, Glavni stan ratne štampe osnovan je odmah po ulasku u rat sa Srbijom i zamišljen kao središnje mjesto državne propagande i kontrole nad vijestima s bojišnice. Prihvaćani su i novinski dopisnici neutralnih zemalja koje bi se „provodilo“ kroz bojišnicu. KPQ bila je svojevrsna sigurna oaza za mnoge koji nisu bili ratno sposobni ili to nisu htjeli biti. Razne namirnice i potrepštine bile su besplatne, a pri ruci su bili vojnicisluge koji su trebali pružati pomoć novinarima i umjetnicima koji su najčešće obilazili nedavna poprišta ratovanja. ${ }^{33}$

KPQ činili su tako intelektualci različitih godišta koji su iz različitih razloga ušli u službu te im je osnovni zadatak bio posjećivati bojišnicu, sastavljati novinske

28 Zur Eröffnung der Kunstausstellung, Agramer Zeitung, br. 101, 3. 5. 1911.

29 Oswald ÜBeregger, Kulturelle Mobilisierung. Die österreichisch-ungarische Kriegspropaganda gegen Italien, u: Krieg in den Alpen: Österreich-Ungarn und Italien im Ersten Weltkrieg (1914-1918), ur. Nicola Labanca i Oswald Überegger, Wien, 2015., 265. O ulozi propagande u odnosu na raspad Austro-Ugarske vidjeti: Mark Cornwall, The Underminig of Austria-Hungary. The Battle for Hearts and Minds, London - New York, 2000.

30 Steffen Bruendel, Volksgemeinschaft oder Volksstaat. Die „Ideen von 1914“ und die Neuordnung Deutschlands im Ersten Weltkrieg, Berlin, 2003., 46.

31 William M. Johnston, Der österreichische Mensch: Kulturgeschichte der Eigenart Österreichs, Wien, 2010., $64-65$.

32 O hrvatskim intelektualcima i Prvom svjetskom ratu vidjeti: Filip HAMERšAK, Tamna strana Marsa: hrvatska autobiografija i Prvi svjetski rat, Zagreb, 2013.

33 Chris Dubbs, American Journalists in the Great War: Rewriting the Rules of Reporting, Lincoln, 2017., 70 . 
tekstove, propagandne materijale, raditi skice s bojišta itd. Mnogima je bilo dozvoljeno vraćati se kući s fronte kako bi mogli dovršiti svoj rad na umjetničkim djelima ili tekstovima. Zapovjednik KPQ bio je pomalo neobičan i ekscentričan general Maximilian von Hoen, kojeg je 1917. godine prema naređenju cara Karla I. zamijenio pukovnik Wilhelm Eisner-Bubner s ambicioznim planovima agresivnijeg propagandističkog rada. ${ }^{34} \mathrm{U}$ sklopu KPQ služili su tako i Stefan Zweig, Rainer Maria Rilke, Robert Musil, Franz Werfel, Josef Redlich i drugi. Edmund Glaise-Horstenau, časnik austrougarske vojske koji je u Generalštabu bio nadležan za tisak, u autobiografskim zapisima piše: „Glavni stan ratne štampe sastojao se od svih raznih mogućih i nemogućih novinara - ratnih izvjestitelja svih religija i rasa, među njima i visokoobrazovanih ljudi, a i polunepismenih, kako je to bilo s poslom. Tome su se nadodavali brojni crtači i slikari, među njima i takvi kao Adams, Schattenstein, Hollitzer i drugi, koji su svi bili oduševljeni višak latentnog junaštva istrošiti u tako ugodnom miljeu kao što je bila njihova rezidencija u Ostravi - udaljena jedan sat vožnje automobilom od Tješina - osim ako ih dužnost nije privremeno poslala na bojište. (...) Hoen im je bio očinski zapovjednik. Kod Conrada i u Štabu bili su pak sve drugo negoli obljubljeni. Ali i tisak općenito se smatrao izuzetno napornom preprekom, koju bi se najradije zabranilo.“35 Oton Iveković, koji je iza sebe ostavio i „zabilješke ratnog slikara“, objavljivane u međuratno vrijeme u nastavcima, ${ }^{36}$ zapisao je: „Kad sam proboravio nekoliko nedjelja među njima [novinarima KPQ, op. a.], dobio sam tačnu sliku o

34 M. Cornwall, The Underminig of Austria-Hungary. The Battle for Hearts and Minds, 26 - 27. Više vidjeti kod: Peter Plener, Walter Reichel, “Extraausgabee -!”: die Medien und das k.u.k. Kriegspressequartier, Wien, 2015.; Christoph TEPPERBERG, »Wie eine idyllische Sommerfrische « - »Dichtdienst « und »Heldenfrisieren«. Kriegspressequartier und Kriegsarchiv als Instrumente der k. u. k. Kriegspropaganda 1914-1918., u: Die Mittelmächte und der Erste Weltkrieg, ur. M. Christian Ortner, Hans-Hubertus Mack, Wien, 2016., 348 - 376. Oton Iveković opisao je u svojim zapisima promjenu u vodstvu na sljedeći način: „Taj naš idilični život u svjetskom ratu nije trajao dugo. Od vrhovne komande u Tješinu (odio za Ratnu štampu) javljeno je, da se formacija Ratne štampe mijenja. Svaki odio ima svoga komandanta. Slikarski je komandant major Sobička i ima svoje sjedište u Beču, ali potpada pod Vrhovnu komandu Ratne štampe svih odjeljenja kojoj je opet komandant pukovnik Eisner-Bubna. Po toj promjeni nisam više mogao po volji odlaziti i dolaziti V. armiji, jer je samnom raspolagala Vrhovna komanda Ratne štampe, koja me je mogla slati i u druge armije, kako pronađe shodnim. Morali smo se jedinstveno uniformisati. Dobivali smo dnevnice od 10 kruna i 50 filira. Druge su pogodnosti ostale, samo su se dopusti morali moliti (...)“ Oton Ive Ković, Iz zabilježaka ratnog slikara, Riječ, sv. 14, Zagreb, 1931., 13.

35 Edmund Glaise Von Horstenau, Ein General im Zwielicht: K.u.K. Generalstabsoffizier und Historiker, sv. 1, prir. Peter Broucek, Wien, 1980., 331.

36 Prvi su put Ivekovićeva ratna sjećanja u nastavcima objavljivana u listu Slobodna tribuna 1922., ali je izlaženje tih tekstova prekinuto. Potom će kroz 1931. zagrebačka Riječ u 23 nastavaka objaviti preuređena i skraćena sjećanja. 
tome, kako se piše za publiku u pozadini. Oni su u komandama dobivali gotove izvještaje, koje su poslije publicistički 'obrađivali'. Jasno je, da je prva dužnost bila glorificiranje svojih, a omalovažavanje protivnika. Tako su izlazili izvještaji, koji su - kako se sjećamo - slavili na primjer zasluge austrijske vrhovne komande, što su Rusi ušli u Lavov i Przemysl, jer da su se 'naše trupe, ostavivši izmorenog neprijatelja, povukle u unapred dobro utvrđene pozicije po ranijem planu'. Tako je i general Potiorek 'zadavši teške udarce srpskoj vojsci, izvršivši tačno svoj zadatak, napustio Srbiju na veliko razočaranje srpske vojske...' ${ }^{\text {(37 }}$

Glavnom stanu ratne štampe priključili su se i hrvatski umjetnici - Oskar Alexander i Oton Iveković te nešto kasnije Robert Frangeš-Mihanović, ${ }^{38}$ koji su prošli Jugozapadno i Istočno ratište. ${ }^{39}$ Iveković, među njima prvi, početkom 1915. priključio se 5. armiji koja je prebačena na Sočansko bojište pod zapovjedništvom Svetozara Borojevića. Nakon nekoliko tjedana uz vojsku, od toga desetak dana na ratištu, što je "djelovalo dosta štetno na njegove živce“, Iveković se vratio u Zagreb i počeo raditi na svojim crtežima. ${ }^{40} \mathrm{U}$ svojim ratnim zabilješkama manje ili više uvjerljivo nastoji opravdati, iz poslijeratne pozicije, svoj angažman u Velikom ratu. Tako piše da se KPQ-u priključio uz pomoć intervencije Gustava Franka i Slavka Kvaternika, razmišljajući o mogućem prebjegu na frontu i stupanju u kontakt s Jugoslavenskim odborom, ističući: „Jednog zimskog dana 1914. godine odoh do svoga znanca dra Gustava Franka. Objasnio sam mu, kako me kao slikara historijskih slika silno interesuje svjetski rat. Ja, koji živim

37 Oton Iveković, Iz zabilježaka ratnog slikara, Riječ, sv. 5, Zagreb, 1931., 5. Iveković također bilježi svakodnevicu u slovenskoj Postojni gdje je Glavni stan ratne štampe 5. armije još krajem 1915. smješten: „U Postojni smo zajedno konačili u gostionici Arko. Imali smo lijepu prostranu sobu, a jelo smo dali sebi prenositi iz kuhinje armijske komande, koja je bila u susjednom hotelu »Adelsberghof «. Poneki put jeli smo i u oficirskoj menaži i tako upoznali dobro oficire Borojevićeve komande. Tu je bio ogroman broj aristokrata, osim onih, koji su faktično radili na bojnim operacijama (ti nisu bili aristokrati).“Već se 1916. međutim prema njemu stanje pogoršalo, ne samo u raspoloženju već i u uvjetima življenja, radi skupoće, nestašica itd. Oton IvEKović, Iz zabilježaka ratnog slikara, Riječ, sv. 10, Zagreb, 1931., 7 - 8.

38 Prema Ivekoviću, Frangeš-Mihanović priključio se KPQ-u kako ne bi završio na bojištu: „Moj kolega kipar Frangeš također je zamolio generala Borojevića, da ga uzme svojoj armiji. Vidio je, kako se ne moram brinuti za stavnje, pošto sam već 'im Felddienste der Armee', a kako vrag ne spava mogli bi i njega pozvati da 'ajnrikuje'. Njegovoj je molbi bilo odmah udovoljeno i tako smo već krajem septembra zajedno krenuli u glavni stan V. armije (...)“ Oton Iveković, Iz zabilježaka ratnog slikara, Riječ, sv. 10, Zagreb, 1931., 7.

39 Hrvatska - Hrvatski državni arhiv, Zagreb (dalje: HR-HDA), fond 80, Zemaljska vlada - Odjel za bogoštovlje i nastavu (dalje: ZVOBN), kut. 12/80, fasc. 1917/1-60, fol. 35; Hrvatski umjetnici na ratištu, Ilustrovani list, br. 43, 23. 10. 1915. Vidjeti također: D. Alujević, Ratni opus Roberta Frangeša Mihanovića 1915.-1918, Radovi instituta za povijest umjetnosti, sv. 39, Zagreb, 2015., $135-148$.

40 Slikar prof. Oton Iveković vratio se sa ratišta, Jutarnji list, br. 1199, 29. 7. 1915., 4. 
u ovakvo vrijeme, treba da vidim, kako uistinu izgledaju bojišta. Zamolio sam ga, da mi sa svojim vezama isposluje da budem primljen u 'Stan ratne štampe.““41

Međutim, teku kasnijim ratnimgodinama, od 1916., aktivnije se nastoji koristiti istaknute umjetnike i intelektualce i konkretno njihova djela u službi propagande. Tako su u vizualnom smislu austrijski intelektualci putem propagandnih letaka, slika, plakata i drugih ilustracija nastojali evocirati sve jasnije određen segment iz prošlosti Monarhije, dinastije ili - sve više - Austrije. Često posežući pritom prema „velikim ličnostima“ (od princa Eugena Savojskog do nadvojvode Eugena Austrijskog i Svetozara Borojevića ${ }^{42}$ ) ili recentnim prepoznatljivim motivima, primjerice liku Franje Josipa, oni su istovremeno u manjoj ili većoj mjeri popularizirali modernizam ili jedan vid njihova modernizma. $S$ druge strane, propagandistički domet bio je ograničen. Unatoč snažnom utisku koji su imale slike ili kipovi običnih vojnika, ono što je u hrvatskom slučaju nedostajalo je elaborirana strategija buđenja i kontroliranja emocija (emocionalizacija) kod civilnog stanovništva u odnosu na rat (putem propagande). Veliku kočnicu predstavljao je pritom austrougarski politički sustav, odnosi između Beča i Budimpešte i neriješeni problemi iz 19. stoljeća, pa se primjerice izbjegavalo koristiti povijest - inače vrlo snažan element ratne propagande.

Politička i idejna polarizacija hrvatskih umjetnika pritom također dolazi još jasnije na vidjelo. Proširena paranoja i činjenica da se, za razliku od austrijskog Ministarstva rata koje je umjetnicima i intelektualcima moglo dodijeliti i pozamašne financijske potpore kao dodatan poticaj, nije moglo ulagati na takav način u značajne kulturne manifestacije i protumanifestacije, značile su isprva pojačanu, iako ne pretjerano dosljednu cenzuru. Osim toga se provodio određen damnatio memoriae nekih istaknutih pojedinaca, među kojima je bio i Ivan Meštrović. Balansirani ili umjereno kritički tonovi javljaju se uglavnom izvana. Tako likovni kritičar Arthur Roessler, nezavršeni proponent Wickhoffove bečke škole povijesti umjetnosti i veliki podražavatelj Egona Schielea, u svojim esejima pod naslovom Kritische Fragmente: Aufsätze über österreichische Neukünstler [Kritički fragmenti: eseji o novim austrijskim umjetnicima] posvećuje pažnju i Ivanu Meštroviću, nastojeći impresionistički povezati analizu stila, svojstveno estetičko čitanje i kritiku modernosti te osudu Meštrovićeva umjetničkopolitičkog „Zastranjivanja“.43 Židovski kritičar Felix Braun u novinskim

41 Oton Ive Ković, Iz zabilježaka ratnog slikara, Riječ, sv. 5, Zagreb, 1931., 4.

42 Upravo je Robert Frangeš-Mihanović u sklopu svojeg ratnog angažmana izradio konjanički portret Eugena Austrijskog i reljef Svetozara Borojevića. Na to ukazuje novije istraživanje Darije Alujević. D. Alujević, Ratni opus Roberta Frangeša Mihanovića 1915.-1918, 143.

43 Arthur Roessler, Kritische Fragmente, Aufsätze über österreichische Neukünstler, Wien, 1918. 
tekstovima Fremden-Blatta još 1917. godine kritizira stanje umjetnosti u Beču i Austro-Ugarskoj, predbacujući nedostatak infrastrukture, podrške i davanja dostatnog prostora umjetničkim talentima kojih, prema njegovim riječima, nikako ne nedostaje. Spominjući i Meštrovića kao ostvarenog umjetnika koji se ističe među slavenskim modernističkim predstavnicima, Braun ustvari želi premostiti jaz između etabliranih i novih generacija umjetnika naglašavajući kako je tomu rezultiralo modernističko promišljanje uloge umjetnosti i umjetnika u društvu. ${ }^{44}$

\section{MEŠTROVIĆEVE PROTUAUSTROUGARSKE PROPAGANDNE TURNEJE U VELIKOJ BRITANIJI}

U međuvremenu su Meštrovićevi umjetnički uspjesi ipak dakako izbjegavani, ali kulturna politika koju je provodio u sklopu Jugoslavenskog odbora činila je bitnu komponentu djelatnosti tog odbora. Meštrović je naime već 1914. godine uoči atentata prijestolonasljednika Franje Ferdinanda, nakon zabrane planirane splitske izložbe radova u sklopu Medulića, napustio Austro-Ugarsku. ${ }^{45} \mathrm{Iz}$ Rima je potom koristio situaciju kako bi svoje prijatelje i istomišljenike potakao na emigraciju i okupljanje u Italiji. Tako na izričito Meštrovićevo traženje dolazi Milan Marjanović, ali i drugi intelektualci - Franko Potočnjak, Hinko Hinković, Dinko Trinajstić i drugi. ${ }^{46}$ Od konstituiranja Jugoslavenskog odbora i 1915. pa nadalje, Meštrović poduzima dugoročnu kulturnu turneju po Velikoj Britaniji kao praktično ostvarenje idejnih nastojanja oko jugoslavenskog umjetničkog stila. Ključne su pritom izložbe njegovih radova i međunarodna pozornost koju su posredstvom britanskih prijatelja izazvale među silama Antante, naravno u kontekstu trajanja Velikog rata. Kada 1915. kreće na tu kulturnu turneju, bitno je bilo objasniti, Meštrovićevim riječima - da jugoslavenstvo postoji na kulturnom planu, a da je u odnosu na Hrvate ili Srbe kao Britanija u odnosu na Engleze ili Škote. ${ }^{47}$ Za razliku od toga 1918. i završetak turneje s izložbama ukazuje na veliki uspjeh propagande jugoslavenstva, odnosno politike Jugoslavenskog odbora i britanskih prijatelja u samoj Velikoj Britaniji.

Pritom se $u$ idejnom smislu neka njegova djela predstavljaju u novom, politički i ideološki jasnijem ili pojačanom kontekstu. Raniji Meštrovićevi

\footnotetext{
44 Alte und neue Kunst in Österreich, Fremden-Blatt, br. 112, 25. 4. 1917.

45 I. Meštrović, Uspomene na političke ljude i dogadaje, 37 - 38.

46 I. MEŠTrović, Uspomene na političke ljude i dogadaje, 38.

47 I. MEŠTrović, Uspomene na političke ljude i dogadaje, 54.
} 
pothvati ponovno dobivaju pojačani jugoslavenski predznak: tako primjerice 1915. godine Ljubo Leontić retrospektivno na izložbe Meštrovića i Mirka Račkog (1910.) te izložbu „Nejunačkom vremenu u prkos“ gleda kao na „prolog, uvertiru velikog pohoda““ ${ }^{48}$ Leontić naime prikazuje komponente „jugoslavenskog kulturnog jedinstva“, počevši od književnosti i glazbe, a završavajući s kiparstvom i slikarstvom, odnosno Meštrovićem. Poput Njegoša i Mažuranića, i Meštrović je za njega „najuzvišenija emanacija patničke i velike jugoslovenske narodne duše“. ${ }^{9}$

Pomoć pri organizaciji kulturnih pothvata Meštroviću su pružali politički aktivni povjesničar, novinar i urednik uglednog The Times Henry Wickham Steed te osobito povjesničar Robert Seton-Watson, koji su uvidjeli propagandni potencijal tih manifestacija. ${ }^{50}$ Robert Seton-Watson bio je pritom ključna osoba, ne samo zbog činjenice da su ga stručni interesi godinama vezali uz srednjoeuropski prostor i slavenski element Habsburške Monarhije već i zato jer je od početka rata stupio u kontakt $s$ britanskim uredom za vanjske poslove te je kao novinar i povjesničar imao političkog utjecaja. ${ }^{51}$ Upravo je SetonWatson, nezadovoljan tajnim Londonskim sporazumima iz travnja 1915., odlučio podržati agresivniju propagandu južnoslavenskih zemalja kao kulturno diferenciranih u odnosu na njemačko i mađarsko stanovništvo Habsburške Monarhije. Preko Frane Supila dogovoren je početak kulturne turneje radova Ivana Meštrovića u Londonu, kao velebna manifestacija s uglednim pripremnim odborom i uzvanicima. ${ }^{52} \mathrm{Zbog}$ toga je Meštrovićevo stvaralaštvo dobilo pojačan

48 s. a. [Ljubo Leontić], Jugoslavensko kulturno jedinstvo, Jadran, sv. 53-58, Buenos Aires, 1916. 28 - 30. Usp. Norka Machiedo Mladinić, Prilog proučavanju djelovanja Ivana Meštrovića u Jugoslavenskom odboru, Časopis za suvremenu povijest, sv. 39/1, Zagreb, 2007., 142; V. SRHOJ, Ivan Meštrović i politika kao prostor ahistorijskog idealizma, 369 - 384.

49 LJ. LEONTIĆ, Jugoslavensko kulturno jedinstvo, 29.

so Usp. I. MešTrović, Uspomene na političke ljude i dogadaje, 55; Maria MešTrović, Život i djelo Ivana Meštrovića, Zagreb, 2011., 93. R. W. Seton-Watson već je ranije sudjelovao u pamfletu, primjerice "The Spirit of the Serb“ koji je sam sastavio, te različitim drugim tekstovima, predavanjima i nastupima. Godine 1916. pokrenuo je i izdavao list New Europe. Do sredine rata Seton-Watson predvodio je korpus stručne i propagandističke literature o ,jugoslavenskom pitanju“, pored diplomata Victora Bérarda, pisca i kriminologa Rudolphea Archibalda Reissa i drugih. Usp. $R$. W. Seton-Watson i Jugoslaveni. Korespondencija 1906-1941, sv. 1: 1906-1918, ur. Ljubo Boban, et al., Zagreb - London, 1976., 201 - 202. Vidjeti: Arthur J. MAY, R. W. Seton-Watson and British AntiHapsburg Sentiment, American Slavic and East European Review, sv. 20, Cambridge, 1961., 40 - 54.

51 Usp. I. Meštrović, Uspomene na političke ljude i dogadaje, passim.

52 I. Meštrović, Uspomene na političke ljude i dogadaje, 49. Odbor su tako činili Mateja Bošković, srpski veleposlanik u Londonu, George Curzon, nekadašnji potkralj Indije i utjecajan političar, nadbiskup Westminstera i prelat Katoličke crkve Francis Bourne, lord Arthur Balfour, ministar trgovine Walter Runciman, ministar blagajne i financija David Lloyd George, zatim niz umjetnika i intelektualaca poput kipara Augustea Rodina i Johna Tweeda, slikara Johna Singera Sargenta, 
politički značaj, a kulturna misija pretvorila se ustvari isključivo u političku. Radovi su tajno dopremljeni u London kako intencije ne bi spriječila austrijska vlada; dio izložaka dopremljen je iz Splita i Beograda, dok neki radovi iz Zagreba i drugih gradova nisu mogli biti dostavljeni. ${ }^{53}$

Na stranicama Savremenika među redovima se iščitava podupiranje kulturne politike Meštrovića i Jugoslavenskog odbora: u veljači 1915. u prilogu „Kulturni radnici i Svjetski rat“ ističe se važnost „kulturne snage jednog naroda“, dapače ključnu ulogu u očuvanju narodnosti - a da će realizacija aktualnih političkih programa (jugoslavenstva) morati osigurati kulturnu snagu. ${ }^{54}$ Sam pohod u Velikoj Britaniji počeo je u najvećem svjetskom muzeju dekorativne umjetnosti: Victoria and Albert Museum u Londonu izložio je na ljeto 1915. Meštrovićeve radove. Izložbu su otvorili britanski državni tajnik za vanjske poslove Lord Robert Cecil te nakon njega nekadašnji ministar prosvjete J. A. Pease, a među uzvanicima bili su bitni predstavnici kulturnih i političkih elita - od novinara $\mathrm{H}$. G. Wellsa, indijskog filozofa Ananda Coomaraswamyja do Milenka Vesnića kao srpskog poslanika u Parizu i supruge srpskog premijera Nikole Pašića. ${ }^{55}$ Britanski tisak bilježi veliki interes u glavnom gradu za izložbu koja je nesvakidašnji „OneMan Show“ jednog autentičnog umjetnika koji dokazuje slavensku kulturnu individualnost $s$ jedne strane te povezanost sa zapadnoeuropskim (najčešće talijanskim ili francuskim) civilizacijskim sferama. ${ }^{56}$ Novine u opisima izložbe često navode i njegovo djetinjstvo, dalmatinski krajolik, pastirske dane, nagon da stvara „sirove dekorativne rezbarije“ i inspiraciju u narodnoj lirici koju pretvara u demonstraciju nacionalne moći, ponosa i bijesa. ${ }^{57}$

Dodatnu promociju izložbe provodilo je i nezavisno humanitarno društvo, tzv. Srpski potporni fond (Serbian Relief Fund), koji je izložbu razglašavao uz

novinara i povjesničara Valentinea Chirola, likovnog kritičar The Timesa A. Cluttona Brocha, povjesničara Georgea Macaulayja Trevelyana, arheologa Arthura Evansa i drugih. Prema navodima Marije Meštrović, D. H. Lawrence otkupio je jedan kip, a W. B. Yeats izložbu je posjetio četiri puta. M. Meštrović, Život i djelo Ivana Meštrovića, 91 - 92.

53 Milan Marjanović, Meštrovićeva izložba u Londonu, Jadran, br. 53-58, Buenos Aires, 1916. 32. Tako piše i Božo BAnAc u London R. W. Seton-Wastonu. R. W. Seton-Watson i Jugoslaveni. Korespondencija 1906-1941, sv. 1: 1906-1918, ur. Ljubo Boban, et al., Zagreb - London, 1976., 189. Pritom je zanimljivo ustvrditi da ni u diplomatskom ni u propagandnom smislu nije od strane Austro-Ugarske ništa posebno poduzeto da se tim potezima kontrira.

54 S. a., Kulturni radnici i Svjetski rat, Savremenik, br. 1-2, Zagreb, 1915., 1 - 3, ovdje 3.

55 I. MEŠTrović, Uspomene na političke ljude i dogadaje, 54.

56 Maria Meštrović piše da je to bio prvi put da taj britanski muzej priređuje samostalnu izložbu živućem umjetniku, iako je ustvari prva takva izložba bila ona djela Augustea Rodina 1914. godine. M. MešTrović, Život i djelo Ivana Meštrovića, 90 - 91.

57 The Art of Ivan Meštrović: The One-Man Show at a Museum, Illustrated London News, br. $3977,10$. 7. 1915 . 
sljedeći naslov: „Nepokoriva Srbija, poput našeg drugog galantnog saveznika Belgije, plaća cijenu otpora okupatoru ... Ona se borila i porazila Austrijance: sad se treba boriti protiv oskudice, bolesti, i gladi ... Molimo za vaš prilog danas. “58 Propagandistička svrha izložbe nije skrivana, već je dapače medijski prostor korišten za daljnje poruke i južnoslavensko agitiranje. Milan Marjanović piše za Jadran, list Hrvata koji je od 1915. nadovezujući se na list Sloboda izlazio u Buenos Airesu, također o golemom uspjehu izložbe i kapitalu koji ta kulturna manifestacija donosi za jugoslavensku politiku. ${ }^{59}$ Među rijetkim kritičkim glasovima javio se u britanskom tisku onaj umjetnika Selwyna Imagea, koji nije dovodio u pitanje Meštrovićev talent, ali je kritizirao izložena djela kao znak „morbidnih i opakih artističkih tendencija“, odbacujući ih u estetskom smislu. ${ }^{60}$ Znakovito je kako hrvatske novine vijesti prenose od njemačkih, unose neke korekcije (Meštrović je u njemačkom tisku bio Mestrovio), navode kako je s ostalim „Srbima“ protjeran iz Italije 1914. godine te kako u Velikoj Britaniji napokon postiže željeni uspjeh bez osporavanja. ${ }^{61}$

No nije sve prošlo i bez skandala. Naime, Meštrović se protivio ideji da bude razglašavan kao „srpski umjetnik“, a ne ,jugoslavenski““62 Osim što su izložbe koje su upriličene u Velikoj Britaniji između 1915. i 1918. godine dosezale šire mase i slale različite poruke, od razjedinjenosti i slabosti Habsburške Monarhije

58 James Fox, British Art and the First World War, 1914-1924, Cambridge, 2015., 59 - 61. Treba napomenuti da inače interesantna interpretacija britanskog autora donosi i neke netočnosti.

59 M. Marjanović, Meštrovićeva izložba, 32. Milan Marjanović ranije je već u New Yorku, u sklopu svoje propagandne turneje po Sjevernoj i Južnoj Americi, gdje je kod iseljeništva agitirao u korist Jugoslavenskog odbora, objavio manju knjigu Genij jugoslovenstva: Ivan Meštrović i njegov Hram. Osim toga je pisao i kraće osvrte na Meštrovićeve izložbe, osvrtao se na njega u predavanjima i govorima. Milan Marjanović, Ivan Meštrović: prorok i slava jugoslovenstva, New York, 1915.

60 Ivan Mestrovic: British Professor's Protest, The Globe, br. 37.448, 30.6. 1915., 6. Image se u narednim danima oglašavao dalje u Globeu i Timesu.

61 Meštrović u Londonu, Jutarnji list, br. 1188, 18. 7. 1915., 6.

62 Usp. I. Meštrović, Uspomene na političke ljude i dogadaje, 54 - 55; M. Meštrović, Život $i$ djelo Ivana Meštrovića, 89 - 90. Christopher i Hugh Seton-Watson donose i pobliže objašnjenje te situacije: „Razlog za odlaganje (primanja članova Jugoslavenskog odbora u , op. a.) bilo je protivljenje srpskog poslanika u Londonu, M. Boškovića, koji je bio usko srpskog gledišta i pokazivao najveću sumnjičavost prema pojmu „Jugoslaven“ te smatrao da su Južni Slaveni, čak i pravoslavni Srbi, opasno zaraženi razornim utjecajem srednjoevropske, manje ili više germanizirane kulture. Bošković je čak odbio da prisustvuje otvaranju izložbe Meštrovićevih kipova u Victoria i Albert Museumu u Londonu 24. lipnja 1915. ukoliko Meštrović ne pristane da se proglasi Srbinom. Kako je Meštrović odbio da mu se tako naređuje, bilo je potrebno pozvati Vesnića, srpskog poslanika u Parizu, da dođe na otvaranje. Izložba, koje je glavni organizator bio Seton-Watson, bila je veliki uspjeh i mnogo je pridonijela da je britanska publika postala svjesna jugoslavenskog pitanja." Christopher Seton-Watson, Hugh Seton-Watson, „R. W. Seton-Watson i Jugoslaveni“, u: $R$. W. Seton-Watson i Jugoslaveni. Korespondencija 1906-1941, sv. 1: 1906-1918, ur. Ljubo Boban, et al., Zagreb - London, 1976. 
do dokaza da postoji nepobitna povijesna povezanost južnoslavenskih naroda i da je Jugoslavija upravo organički prirodan korak po svršetku rata, one su bile i dodatan prostor povezivanja i posredovanja među različitim stranama: od istaknutih intelektualaca iz Velike Britanije do predstavnika Srbije ili drugih zemalja Austro-Ugarske, poput Tomaša Masaryka i Edvarda Beneša. Meštrović u svojim memoarima sam naglašava ulogu tih izložba, napominjući kako je za njega to bio primarni vid funkcioniranja Jugoslavenskog odbora; slično će važnost izložbi naglasiti i Aleksandar Karađorđević u kratkom pariškom razgovoru. ${ }^{63}$ Nakon Londona, Meštrović izlaže samostalno u Leedsu gdje, uz pomoć Milana Marjanovića, drži i predavanje. ${ }^{64}$ Zatim ima izložbe u Škotskoj u Edinburghu, Glasgowu i Aberdeenu, pa ponovno u Londonu na zajedničkoj izložbi srpskohrvatskih umjetnika, da bi 1918. godine uspio upriličiti još izložbe u Bradfordu, Glasgowu i Edinburghu. Britanski tisak neprestano hvali Meštrovićeve izložbe i koristi svaku priliku da pritom što kritičnije označi situaciju u Habsburškoj Monarhiji ${ }^{65}$ Do izražaja ne dolazi samo teza o,,tamnici naroda“(Völkerkerker), koji pod liberalnom paskom Antante dakle itekako mogu svoju slobodu usmjeriti u kulturno stvaralaštvo, već i tematiziranje antimodernosti Habsburške Monarhije, ne samo u političkom nego i kulturnom planu. Isto tako je velik naglasak stavljen na Srbiju. Što zbog pogrešaka iz neznanja, što iz propagandnih razloga, kako bi čitateljima ciljevi i ratno savezništvo djelovali što bližim, hrvatski su slikari, od Meštrovića do Rosandića i Račkog, predstavljani kao „srpski umjetnici“. Isto se nije dogodilo krajem 1917. na londonskoj izložbi spomenutog trojca: naglasak je tada bio na južnoslavenskoj glazbi, a niz je uglednih intelektualaca održao prigodna predavanja. ${ }^{66}$ Sredinom 1918., u sklopu Meštrovićeve turneje, u Edinburghu je tako održano predavanje o povijesti Srbije u kojem je opisan procvat srpske umjetnosti nakon oslobođenja od Osmanskog Carstva. ${ }^{67}$ Kako bi se dodatno pojačao medijski interes u posljednjoj godini turneje, izložbe i Meštrovićeva pojavljivanja vezana su uz takva predavanja, prezentacije ratnih fotografija i slika iz Srbije ili manjih svečanosti poput predstavljanja Meštrovićeva poprsja Elsie Inglis, škotske liječnice koja je djelovala u Srbiji tijekom rata.

63 I. MešTrović, Uspomene na političke ljude i dogadaje, 83.

64 Publicist i novinar Josip Jedlowski javlja u Jadranu kako su izložba i prijem Meštrovića u Leedsu dokazali da „hladna engleska duša"cijeni iskonsku umjetnost i talent nad bilo kakvom propagandom - želeći možda i nehotično umanjiti propagandni karakter izložbe. S. a. [Josip JEDLOwSKI], Ivan Meštrović u Leeds-u, Jadran, br. 516, Buenos Aires, 1915., 2.

65 Postojala je i zamisao da se Meštrovićeva izložba organizira i u Rusiji odnosno Sankt-Peterburgu, ali je ta mogućnost otpala. M. MešTrović, Život i djelo Ivana Meštrovića, Zagreb, 107.

66 Ivan Pederin, Stadler, Pilar i Jugoslavenski odbor u Londonu 1917./1918., Croatica Christiana periodica, sv. 29., Zagreb, 2005., 174.

67 Serbian History and Art, The Scotsman, br. 14565, 18. 5. 1918., 4. 
U međuvremenu su defenzivne dojavne službe na području Hrvatske putem svojih mreža špijuna sakupljale podatke o kretanju najistaknutijih građana $u$ emigraciji, ističući pritom Meštrovićevu političku involviranost i prisutnost u svim centrima neprijateljske propagandne - pritom prvenstveno misleći na Rim i London. Izvještaji se međutim bave numeričkim podatcima o listovima i člancima koji u zemljama Antante izlaze kao projugoslavenski i prema Monarhiji neprijateljski, dok se iscrpniji uvidi i opisi kulturnih manifestacija već u samim internim izvještajima svode na vrlo naivne propagandne fraze, povremenu porugu i upitne ili pojednostavljene interpretacije. K. u. k. Kriegspressequartier paralelno je $s$ velikim uspjesima Meštrovićeve turneje pripremao vlastite kulturno-propagandne akcije.

\section{AKTIVNOSTI I PROTUODGOVORI U AUSTRO-UGARSKOJ OD 1915. GODINE}

Počevši od 1915., ali aktivnije tek od 1916., pokrenut je niz kulturnoumjetničkih izložbi u Austro-Ugarskoj te neutralnim zemljama, kao i zemljama saveznicima Centralnih sila. Grupa od oko 150 umjetnika iz čitave Habsburške Monarhije do sredine 1917. stvorila je korpus od oko 7500 crteža, slika i kipova. ${ }^{68} \mathrm{U}$ sklopu „Velike umjetničke izložbe u Berlinu“ (održavane u Berlinu i Düsseldorfu tijekom rata) izloženo je austrougarsko ratno slikarstvo, a izložbe „umjetničke sekcije“ KPQ-a različitih koncepcija (osim u Beču) upriličene su i u Budimpešti (1915. - 1917., nekoliko izložbi, ratne slike i drugo), Grazu (1915. - 1918.), Villachu (1915. - 1918.), Stuttgartu (1915.), Frankfurtu (1915. - 1918.), Hamburgu (1916. - 1918.), Ženevi (1916., ratne slike), Bregenzu (1916., ratne slike), Detmoldu (1916.), Lavovu (1916.), Pragu (1916.), Bolzanu (1916. - 1917., ratne fotografije i slike), Brnu (1916. 1918., „Balkanska izložba“), Innsbrucku (1916. - 1918.), Klagenfurtu (1917.), Bukureštu (1917.), Kölnu (1917.), Krakovu (1917.), Amsterdamu (1917., plakati izložba), Konstantinopolu (1917. - 1918.), Darmstadtu (1918., ratne grafike), Bremenu (1918.), Wrocławu (1918.) i Dresdenu (1918.), kao i nekim drugim monarhijskim i njemačkim gradovima. ${ }^{69}$

68 Eberhard Demm, Censorship and Propaganda in World War I: A Comprehensive History, New York, 2019., 75.

69 Österreich [Austrija] - Österreichisches Staatsarchiv - Kriegsarchiv [Austrijski državni arhiv Ratni arhiv] (dalje: AT-OeStA), Wien, FA AOK KPQ Akten 45, Kunstgruppe, Ausstellungen A-K, fasc. 45 . 
Između 1915. i 1918. naglasci su se u izložbama mijenjali, od inicijalne želje da se bojište poveže $s$ unutrašnjošću i izazove angažman civilnog stanovništva, preko nastojanja da se prikaže povezanost saveznika, odnosno Centralnih sila, do potrebe stvaranja mjesta sjećanja u kolektivnoj memoriji i na kraju stvaranja svojevrsne „ratne baštine“ za buduće generacije. Ivekovićeva sjećanja otkrivaju pritom kako je 1917. za amsterdamsku izložbu „umjetnička sekcija“ dobila naputak da se dodatno traže ratne slike „bez agresivnih tendencija“, odnosno koje su „uglavnom iz mirnodopskog vremena“.70

$\mathrm{Na}$ inicijalni prijedlog Društva umjetnosti, i dalje pod kontrolom Izidora Kršnjavog, u Zagrebu je također u listopadu 1916. u Sveučilišnoj knjižnici priređena izložba ratnog slikarstva. ${ }^{71}$ Među velikim brojem umjetničkih izložaka uvršteni su i radovi Oskara Alexandera, Roberta Frangeša-Mihanovića i Otona Ivekovića. ${ }^{72}$ Sam Iveković izradio je vrlo upečatljiv plakat izložbe. ${ }^{73}$ Organizaciju izložbe preuzeo je službeno, uz Društvo umjetnosti, „Zitin dom“ i „Gospojinski odbor za ratnu pripomoć“ te uz pokroviteljstvo predstavnika dinastije Habsburg u Zagrebu Leopolda Salvatora, koji je inače često sponzorirao takve manifestacije. Tom prigodom izdan je i kraći katalog izložbe s predgovorom generala Maximiliana von Hoena: osim općih misli o ratu i ratnoj stvarnosti, Hoen ističe kako izložba obilazi gradove Monarhije i šire, napominjući da „šaljemo i u Zagreb crteže i djela iz Galicije, Poljske i Rusije, sa Balkana i granica Italije, nevjerne zemlje, da potaknu zahvalno sjećanje na naše hrahre (sic) čete u polju“ ${ }^{74}$

Cilj izložbe bio je dakle utemeljiti u imaginariju stanovništva udaljenog od fronta mjesta sjećanja i pamćenja, potičući upravo putem prikaza tih mjesta različite patriotske i druge osjećaje. Iako za razliku od bečke ratne izložbe (također 1916.), koja je bila osmišljena kao tematsko-zabavni park nalik na predratne manifestacije i koju je posjetilo u dva mjeseca oko pola milijuna posjetitelja, ${ }^{75}$ u Zagrebu nije bilo ni sredstava ni mogućnosti da se upriliči

70 Oton Iveković, Iz zabilježaka ratnog slikara, Riječ, sv. 22, Zagreb, 1931., 10.

71 AT-OeStA, Wien, FA AOK KPQ Akten 45, Kunstgruppe, Ausstellungen A-K, fasc. 45.

72 Izložene su četiri Alexanderove slike („Boj u zraku“, „Pilot satnik Ferdinand vitez pl. Cavallar“, „Pomorski poručnik“, „Pilot pukovnik Uzelac“) te petnaest brončanih i sadrednih kipova Roberta Frangeša-Mihanovića (portretni reljefi nadvojvode Eugena, general-pukovnika Svetozara Borojevića, zapovjednika Stjepana Sarkotića, šefa generalnog stožera Aurela Le Beaua te drugi modeli). Preko sedamdeset akvarela, ulja na platnu ili crteža s najrazličitijim motivima Otona Ivekovića činili su jednu od okosnica izložbe.

73 Hrvatska - Nacionalna i sveučilišna knjižnica, Grafička zbirka, Izložba ratnih slika u Zagrebu, C-PXXVIII-1/89.

74 s.a. Umjetnička izložba c. i kr. konaka ratne štampe, Zagreb, 1916., 5.

75 Maureen HeAly, Vienna and the Fall of the Habsburg Empire: Total War and Everyday Life in World War I, Cambridge, 2004., 88. 
tako ambiciozan projekt, ipak je cilj izložbe ostao isti: upoznati posjetitelje $s$ iskustvom rata koji je opravdan. Američka povjesničarka Maureen Healy je analizirajući bečku izložbu zaključila da joj je glavna svrha bila građane, za koje se smatraju da samo djelomično shvaćaju što je rat, upoznati s totalitetom rata te pojačati osjećaj povezanost vojske na fronti i ljudi koji su ostali kod kuće; ta su dva međusobno povezana cilja izložbe i na primjeru zagrebačke manifestacije jasno uočljiva. ${ }^{76}$ Ali i ograničenja zagrebačke izložbe dolaze brzo na vidjelo - skromno medijsko pokriće i nedostatak popratnih sadržaja koji trebaju multiplicirati u osjećajnom smislu shvaćanje iskustva rata. Ni velika najava da će se otkupljeni reljef Franje Ferdinanda, „prve Antantine žrtve“, iskoristiti za spomenik na Mirogoju, nije ostvarena. ${ }^{77}$ Izidor Kršnjavi spominje da je Ivan Bojničić, ravnatelj Zemaljskog arhiva, planirao i pripremio paralelnu izložbu povijesnog ratnog slikarstva. Dan prije njezina otvorenja po nalogu je zabranjena, radi „izazovnih slika“ iz ratnih godina 1848 . i 1849 . godine. ${ }^{78} \mathrm{Na}$ taj način poništen je nacionalno-povijesni aspekt, nešto što su Meštrovićeve britanske izložbe nužno sadržavale, dakako u kontekstu jugoslavenstva.

Još je jedna izložba 1916. organizirana na poticaj Društva umjetnosti, a pod protektoratom velikog župana Virovitičke županije Ivana AdamovićaČepinskog: u Osijeku je pripremljena izložba hrvatskih umjetnika „za hrvatske junake, nemoćnike i ranjenike“. Neka djela Ivekovića i Frangeš-Mihanovića izložena su u Osijeku ponovno, uz ona Rudolfa Valdeca, Vjere Bojničić, Naste Rojc, Dore Car, Branka Šenoe, Ferda Kovačevića, Bele Čikoša Sesije i drugih. ${ }^{79}$ Izložba je međutim u tisku kritizirana kao nedovoljno uspjela jer nije reprezentirala sve hrvatske umjetnike; stari sukob „starih“ i „mladih“, zapravo tradicionalnijih umjetnika koji su pod utjecajem Kršnjavog djelovali "patriotski“ i mladih modernista koji su isticali „nacionalizam“ u najširem smislu, slijedeći Meštrovića, na trenutak se ponovno rasplamsao. U Savremeniku Vladimir Lunaček brani nacionalizam kao jedan od sadržaja umjetnika koji je individualan i slobodan; podrazumijevajući nacionalizam kao hrvatski nacionalizam, iako se referirao na djela Meštrovića i drugih, jasno prepoznata kao primjeri ,jugoslavenske“ umjetnosti u stvaranju. ${ }^{80}$

76 M. HeAly, Vienna and the Fall of the Habsburg Empire: Total War and Everyday Life in World War I, 88; 108 - 109. Usp. M. CoRNWALl, The Underminig of Austria-Hungary. The Battle for Hearts and Minds, 27.

77 Personalnachrichten, Neue Freie Press, br. 18814, 5. 1. 1917., 9.

78 I. KRŠNJAVI, Zapisci. Iza kulisa hrvatske politike, knj. 2, 768 - 769.

79 Usp. s. a., Izložba hrvatskih umjetnika u Osijeku 1916 - Hrvatski umjetnici u korist nemoćnika junaka Hrvata, Zagreb, 1916.

80 Vladimir LunAČEK, Hrvatski umjetnici za hrvatske junake, nemoćnike i ranjenike. Izložba u Osijeku - Proljetni salon u Zagrebu, Savremenik, br. 3-4, Zagreb, 1916., 123 - 133. 
S druge strane, konkretniji planovi Odjela za bogoštovlje i nastavu, mjesta koje je po potrebi moglo djelovati kao svojevrsno ministarstvo kulture za Hrvatsku ili je doista tako djelovalo oko 1900. godine i do početka rata, u smislu poticanja kreativnih i intelektualnih krugova za ratnu propagandu i diplomatske poruke, ostvaruje se tek 1917. i 1918. Doduše, Odjel je sudjelovao i formalno pri svečanosti dodjeljivanja počasnih doktorata nadvojvodi Eugenu Habsburškom i generalu Svetozaru Borojeviću, prilikom čega je Frangeš-Mihanović izradio njihove reljefne portrete. ${ }^{81}$ Ali i tada ti planovi ne predstavljaju elaborirane propagandne poteze u sklopu šire osmišljene kulturne politike, već samo pojedinačne inicijative. Izvještaji Odjela za bogoštovlje i nastavu o „umjetničkoj sposobnosti“ koji je Oskara Alexandera i osobito Otona Ivekovića prikazivao kao sposobne moderne umjetnike, ističu kako je Iveković u sklopu Stana ratne štampe postigao zapažene uspjehe sa svojim „istinoljubnim“ $i$ „često dirljivim“ prikazima ratne stvarnosti te osobito u sklopu zagrebačke izložbe svojom slikom „Partija sa jugo-zapadne fronte“. 82

Sredinom 1917. godine jedan službeni izvještaj u Budimpešti, koji je u lipnju primio i hrvatski ban Ivan Škrlec (Skerlecz) te Odjel za bogoštovlje i nastavu, govori o potrebi da se osobito treba razviti - „propaganda na kulturnom i gospodarskom polju“ koja je usmjerena prema neutralnim i savezničkim zemljama s ciljem da se kulturne i gospodarske temelje zemlje prikažu „simpatičnima“, jer su neprijateljske zemlje takvu djelatnost već razvile. ${ }^{83}$ Štoviše, predlaže se ozbiljnije upriličenje manifestacija i izložbi koje bi povezivale znanost i umjetnost i prikazivale njihov visoki stupanj razvijenosti, pa se pozivaju Hrvatska i Slavonija da se po tom pitanju uključe. ${ }^{84}$ Ali realizacija lokalnih izložba i sličnih propagandnih manifestacija bila je više nego umjerena, da bi pritom još ukazala i na neke problematične odnose. Problem koji tijekom ratnih godina postaje uočljiv jest da su novoosnovana društva jugoslavenske ili nacionalne (hrvatske i srpske) provenijencije dobila na zamahu i ostala uvelike izvan kontrole Zemaljske vlade, jer su se financirala neovisno o njoj putem

81 Ti su portreti do kraja rata bili postavljeni na samom Sveučilištu, ali su 1919. uklonjeni. D. Alujević, Ratni opus Roberta Frangeša Mihanovića 1915.-1918, 135 - 144. Treba istaknuti da je prema navodima Ivana Meštrovića dodjela počasnog doktorata bio manevar kojim je Jugoslavenski odbor želio posredstvom rektora Frana Barca doći do Svetozara Borojevića te mu poručiti da Hrvati u njemu vide "Jelačića“, ali da se ne treba ponašati toliko Kaisertreu, odnosno da Hrvati ne trebaju spašavati Austriju. Vidjeti: I. Meštrović, Uspomene na političke ljude i dogadaje, 87 - 88.

82 U dokumentu se slika naziva „U Glavnom štabu jugozapadne fronte“ („Im Hauptquartier der Südwestfront"). HR-HDA, f. 80, ZVOBN, kut. 12/80, fasc. 1917/1-60, fol. 1/VI, 2 - 3.

83 HR-HDA, f. 80, ZVOBN, kut. 12/80, fasc. 1917/1-60, fol. 38, 1 - 3.

84 HR-HDA, f. 80, ZVOBN, kut. 12/80, fasc. 1917/1-60, fol. $38,3$. 
donacija i uz pomoć bogatih patrona. Stoga izložbe izvan domene KPQ-a, poput osječke humanitarne Izložbe hrvatskih umjetnika iz 1916., nisu imale posebni propagandistički naboj, iako su na njima izlagana i djela iz ratnih ciklusa. Slučaj slikara Roberta Auera, nastavnika na Obrtnoj školi i profesora na Umjetničkoj akademiji u Zagrebu, secesijskog slikara, pokazuje kako je Odjel imao slabu kontrolu nad događanjima. Odjel se počinje uplitati u slučaj kada prima prijave za protumonarhističko, neprijateljsko i protudržavno djelovanje, odnosno kada Auer ne dobiva poziv za sudjelovanjem na izložbi u Osijeku. Auer je naime navodno već 1914. prijavio neke svoje kolege, među kojima Ljubu Babića i Kostu Strajnića, nakon čega su oni širili vijesti o tome da je Auer "policijski konfidant“ koji nalaže hapšenja. ${ }^{85}$ Auer je 1916. ostao isključen. No afera se nastavila pod novim okolnostima. U 1918., na valu Meštrovićevih uspjeha u Velikoj Britaniji, o kojima su zagrebački intelektualni i umjetnički krugovi bili itekako informirani, mnogi nisu htjeli stajati na „krivoj strani povijesti“. Nacionalno jugoslavenski umjetnički izričaj koji su propagirali Lunaček, Strajinić ili Babić lako se mogao povezati s njihovim djelima, pod uvjetom da su na nekoj od ranijih izložbi izlagali. Čak su i radovi koji s Meštrovićevim idejama, monumentalizmom ili kosovskom fazom nisu imali veze u promijenjenom kontekstu zadnje ratne godine i sve jače jugoslavenske propagande izvan Austro-Ugarske, dobivali takve konotacije. Auer podiže optužbu upravo usmjerenu prema Ljubi Babiću i Kosti Strajniću, isti dvojac koji će i Kršnjavi u svojim Zapiscima označiti kao ključne arbitre umjetničke besmrtnosti ili dekadentnosti na pomolu i osobito nakon nestanka Habsburške Monarhije. ${ }^{86}$ I tisak piše o tim aferama, a Auer i Kršnjavi postajali su svjesni da ni ban Antun Mihalović, Odjel za bogoštovlje i nastavu pod vodstvom Milana Rojca, ni kolege koji su sada većinom bili privrženi ideji kulturnog jugoslavenstva ne pružaju podršku. Na kraju Auer sam zahtijeva kraći odmor, a Odjel mu odobrava - umirovljenje. ${ }^{87}$ Isto tako je Kršnjavi nastojao preduhitriti poteze svojih protivnika (iako nije izbjegao neugodna ispitivanja i ekscesne situacije), te je odstupio s dugogodišnjeg mjesta predsjednika Društva umjetnosti - koje je tako prešlo u ruke novoj državnotvornoj, jugoslavenskoj

85 HR-HDA, f. 80, ZVOBN, kut. 12/80, fasc. 1917/1-60, fol. Izjava; HR-HDA, f. 80, ZVOBN, kut. 12/80, fasc. 1917/1-60, fol. 351; I. KRŠNJAvi, Zapisci. Iza kulisa hrvatske politike, knj. 2, 642. Pritom treba naglasiti i Meštrovićev utjecaj, koji je sezao 1918. u Zagrebu preko Koste Strajinića i drugih njegovih bliskih suradnika. Već se 1911. u vrijeme koncipiranja „protuizložbe“ Meštrovićevom rimskom uspjehu, prema tvrdnjama Izidora Kršnjavog, udaljio jedan izlagač Celestin Medović, koji je na taj način polujavno pokazao svoj politički rezon, makar se to tada još moglo shvatiti i kao nesuglasica na relaciji Medović-Kršnjavi. I. KRŠNJAVI, Zapisci. Iza kulisa brvatske politike, knj. 2, 648.

86 I. KR ̌̌NJAVI, Zapisci. Iza kulisa hrvatske politike, knj. 2, 813 - 815.

87 HR-HDA, f. 80, ZVOBN, kut. 12/80, fasc. 1917/1-60, fol. 12 i 66. 
struji ${ }^{88}$ Iveković i Frangeš-Mihanović karijere će nastaviti i nakon 1918. godine, ulazeći pritom iz faze „ratnog stvaralaštva“, koja će mahom ostati zatomljena ili izostavljena iz njihova opusa, u obnovljeni „jugoslavenski ciklus“, nadovezujući se na angažman u sklopu predratnih jugoslavenski izložbi, Saveza Lade itd. Ivan Meštrović već je, po svršetku svoje britanske kulturne turneje, planirao novu jugoslavensku izložbu u Lyonu ili Parizu, a ostvaruje politički izuzetno nabijenu jugoslavensku izložbu umjetnika u Splitu 1919. godine. ${ }^{89}$ Pokazat će se međutim da je kulturno jugoslavenstvo odslužilo svoju ratnu svrhu, a da, protivno nekim očekivanjima, pod novim okolnostima prve Jugoslavije postupno otvara mnogo više problema i sukoba negoli ih apsorbira. Društvo hrvatskih umjetnika „Medulić“, 350.

89

J. KlJa Ković, U suvremenom kaosu, 92 - 93. Vidjeti više kod: Ljubodrag Dimić, Kulturna politika Kraljevine Jugoslavije, 3 sveska, Beograd, 1996.; Sandi Bulımb ašić, Prilog identifikaciji djela Ivana Meštrovića na izložbama u prva dva desetljeća 20. stoljeća, Radovi Instituta za povijest umjetnosti, sv. 39, Zagreb, 2015., 149 - 162. 

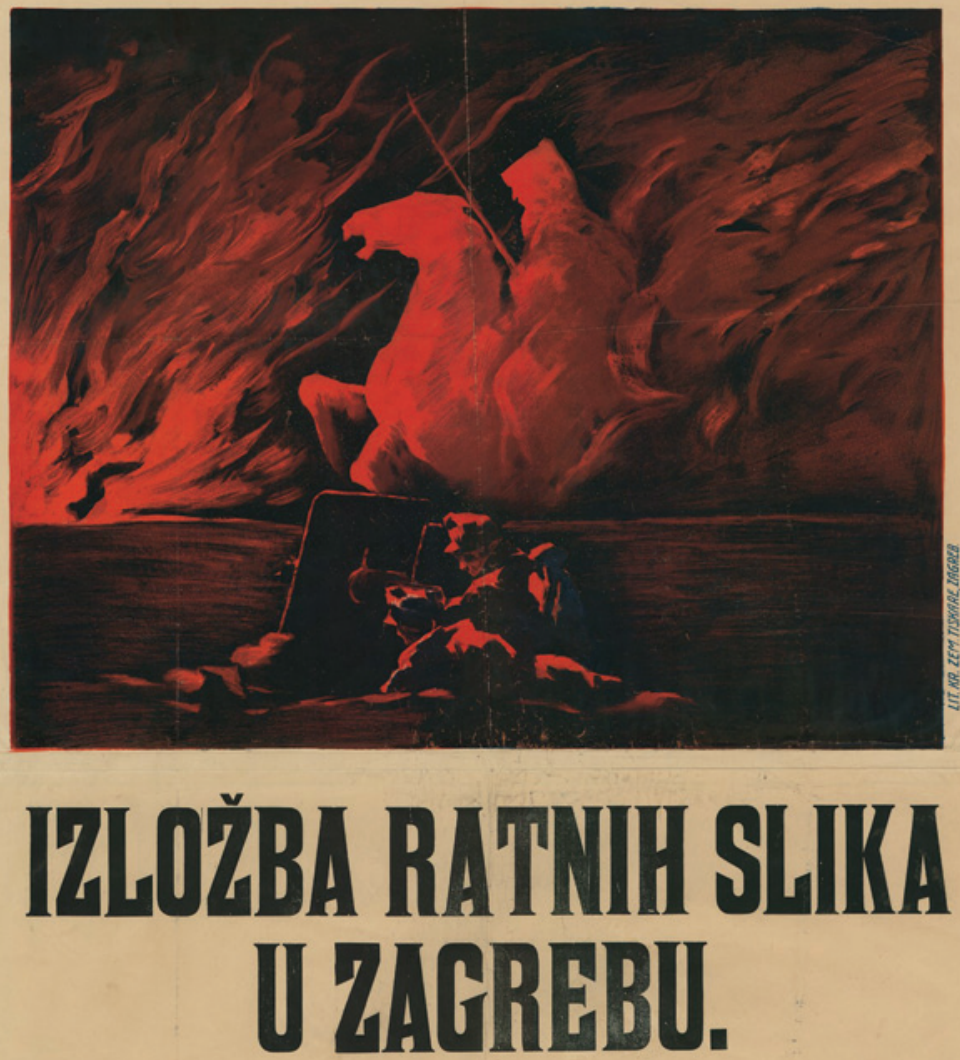

Pod pokrovitelistvom Nj. ces. i kr. Visosti nadvojvode

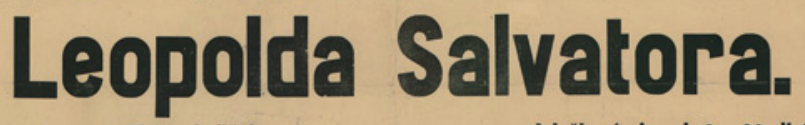

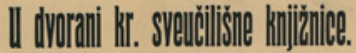

Iabiua traje oll 4.-31. listopalla.

Izložba je ofvorena svaki dan od 9 safi prije podne do 4 safa poslije podne.

Ulaznina po osobi $1 \mathrm{~K}$. Đaci i vojnici 50 fil.

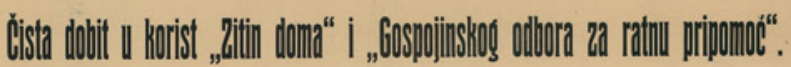

SLIKA 1. Izložba ratnih slika u Zagrebu - plakat Otona Ivekovića iz 1916. godine povodom izložbe u organizaciji KPQ koja je obilazila u različitim koncepcijama Austro-Ugarsku Monarhiju do 1918. godine (Izvor: Grafička zbirka NSK, 000873294) 


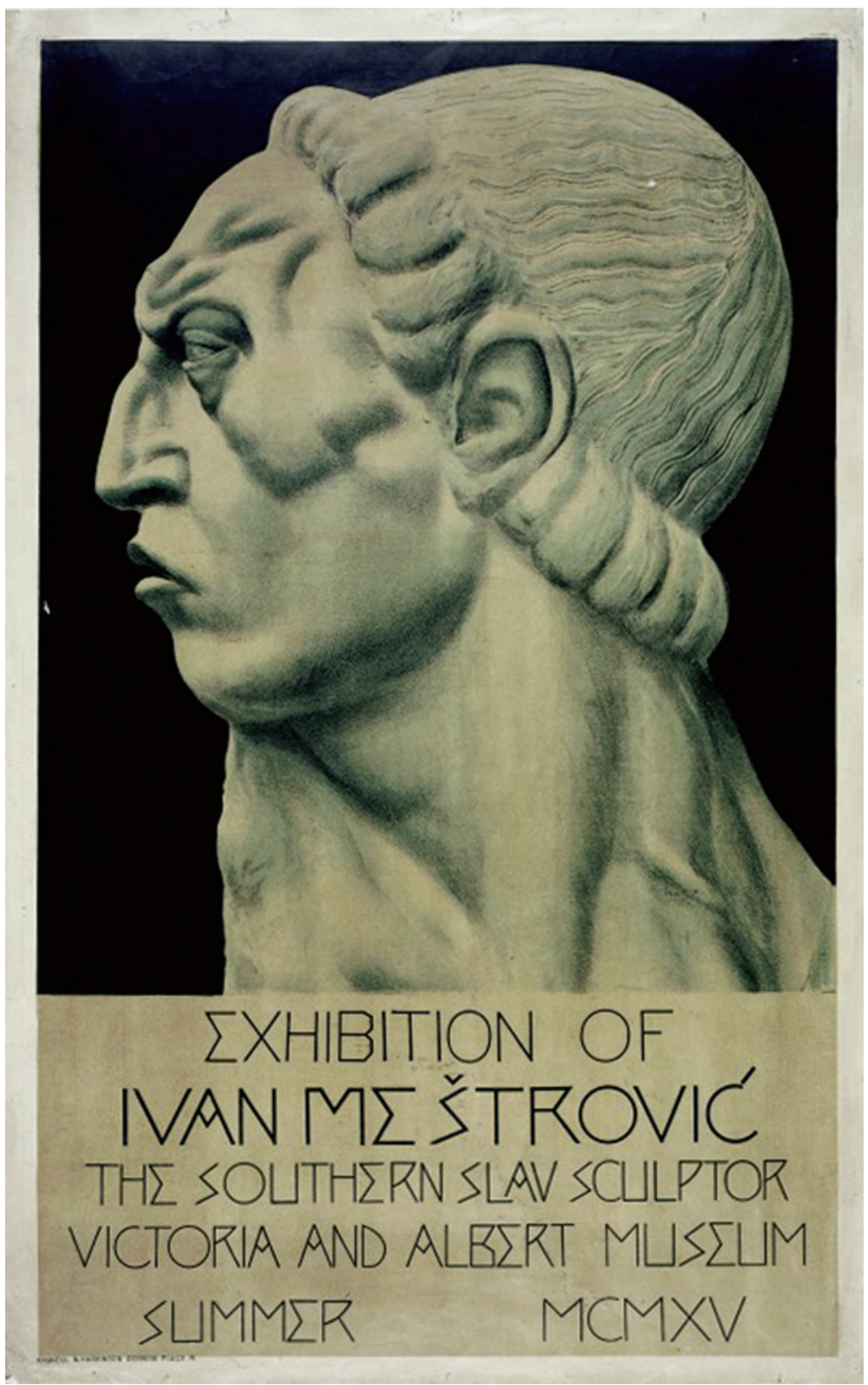

Slika 2. Ivan Meštrović "C The Southern Slav Sculptor "C plakat izložbe Ivana Meštrovića u Londonu 1915. godine koja je označavala početak Meštrovićeve „turneje“ po Velikoj Britaniji do 1918. godine (Izvor: Summary Catalogue of British Posters to 1988 in the Victoria \& Albert Museum in the Department of Design, Prints \& Drawing. Emmett Publishing, 1990., str. 129., dostupno na: https://collections.vam.ac.uk/item/O832432/ivan-mestrovic-the-southernslav-poster-meštrovic-ivan/, (posjećeno 10. prosinca 2021.) 


\section{IZVORI I LITERATURA}

\section{ARHIVSKI FONDOVI I ZBIRKE:}

Hrvatska - Hrvatski državni arhiv, Zagreb, fond 80, Zemaljska vlada - Odjel za bogoštovlje i nastavu

Hrvatska - Nacionalna i sveučilišna knjižnica, Grafička zbirka, Izložba ratnih slika u Zagrebu, C-P-XXVIII-1/89.

Österreich - Österreichisches Staatsarchiv - Kriegsarchiv, Wien, Feldakten, Armeeoberkommando, Kriegspressequartier Akten

\section{NOVINE:}

Agramer Zeitung, 1911.

The Globe, 1915.

Fremden-Blatt, 1917.

Jutarnji list, 1915.

Der Morgen. Wiener Montagblatt, 1910.

Neue Freie Presse, 1911., 1917.

Pester Lloyd, 1911.

The Scotsman, 1918.

Das Vaterland, 1911.

\section{TISKANI IZVORI, OBJAVLJENA GRAĐA I MEMOARSKI SPISI:}

Boban, Ljubo, et al., (ur.), R. W. Seton-Watson i Jugoslaveni. Korespondencija 1906-1941, sv. 1, 1906-1918, Zagreb - London, 1976.

Glaise Von Horstenau, Edmund, Ein General im Zwielicht: K.u.K. Generalstabsoffizier und Historiker, sv. 1, prir. Peter Broucek, Wien, 1980.

Ive Ković, Oton, Iz zabilježaka ratnog slikara, Riječ, sv. 5, Zagreb, 1931., 3 - 5.

Iveković, Oton, Iz zabilježaka ratnog slikara, Riječ, sv. 10, Zagreb, 1931., 7 - 8. IveKović, Oton, Iz zabilježaka ratnog slikara, Riječ, sv. 14, Zagreb, 1931., 13 14.

IveKović, Oton, Iz zabilježaka ratnog slikara, Riječ, sv. 22, Zagreb, 1931., 9 - 10. Jedlows KI, Josip, Ivan Meštrović u Leeds-u, Jadran, br. 516, Buenos Aires, 1915., 2 - 3.

KLJA Ković, Jozo, U suvremenom kaosu. Uspomene i doživljaji, Zagreb, 2011.

KRŠNJAVI, Iso, Zapisci. Iza kulisa hrvatske politike, knj. 2, prir. Ivan Krtalić, Zagreb, 1986. 
Leontić, Ljubo, Jugoslavensko kulturno jedinstvo, Jadran, br. 53-58, Buenos Aires, 1916., 28 - 32.

LUNAČEK, Vladimir, Hrvatski umjetnici za hrvatske junake, nemoćnike i ranjenike. Izložba u Osijeku - Proljetni salon u Zagrebu, Savremenik, br. 3-4, Zagreb, 1916., 123 - 133.

MARJANOvić, Milan, Meštrovićeva izložba u Londonu, Jadran, br. 53-58, Buenos Aires, 1916., $32-33$.

MarJanović, Milan, Vidovdanski hram Ivana Meštrovića, Savremenik, sv. 6, Zagreb, 1919., 272 - 277.

MEŠTrović, Ivan, Uspomene na političke ljude i dogadaje, Zagreb, 1993.

MešTrović, Maria, Život i djelo Ivana Meštrovića, Zagreb, 2011.

Roess Ler, Arthur, Kritische Fragmente, Aufsätze über österreichische Neukünstler, Wien, 1918.

s. a., Kulturni radnici i Svjetski rat, Savremenik, br. 1-2, Zagreb, 1915., 1 - 3.

s.a., Umjetnička izložba c. i kr. konaka ratne štampe, Zagreb, 1916.

s. a., Izložba hrvatskih umjetnika u Osijeku 1916 - Hrvatski umjetnici u korist nemoćnika junaka Hrvata, Zagreb, 1916.

STRAjnić, Kosta, Ivan Meštrović, Beograd, 1919.

\section{LITERATURA:}

Alujević, Darija,m Ratni opus Roberta Frangeša Mihanovića 1915.-1918, Radovi instituta za povijest umjetnosti, sv. 39, Zagreb, 2015., 135 - 148.

BABIĆ, Ljubo, Umjetnost kod Hrvata u XIX. stoljeću, Zagreb, 1934.

BANaC, Ivo, Nacionalno pitanje u Jugoslaviji, Zagreb, 1988.

BARbarić, Damir, (ur.), Fin de siècle Zagreb-Beč, Zagreb, 1997.

BATUŠIĆ, Nikola, KRAVAR, Zoran, ŽMEGAČ, Viktor, Književni protusvjetovi, Zagreb, 2001.

BRALIĆ, Ante, Zadarski fin-de siècle - Političke i društvene prilike u Zadru i Dalmaciji uoči Prvoga svjetskog rata, Časopis za suvremenu povijest, sv. 39, Zagreb, 2007., 731 - 775.

BRUENDEL, Steffen, Volksgemeinschaft oder Volksstaat. Die „Ideen von 1914“ und die Neuordnung Deutschlands im Ersten Weltkrieg, Berlin, 2003.

Bulimbašıć, Sandi, Iso Kršnjavi i Društvo hrvatskih umjetnika „Medulić“, u: Zbornik radova znanstvenog skupa Iso Kršnjavi - veliki utemeljitelj, ur. Ivana Mance i Zlatko Matijević, Zagreb, 2015., 334 - 352. 
Bulimbašić, Sandi, Prilog identifikaciji djela Ivana Meštrovića na izložbama u prva dva desetljeća 20. stoljeća, Radovi Instituta za povijest umjetnosti, sv. 39, Zagreb, 2015., 149 - 162.

Bulimbašić, Sandi, Društvo hrvatskih umjetnika "Medulić" (1908.-1919.): umjetnost $i$ politika, Zagreb, 2016.

Cornwall, Mark, The Underminig of Austria-Hungary. The Battle for Hearts and Minds, London - New York, 2000.

Demm, Eberhard, Censorship and Propaganda in World War I: A Comprehensive History, New York, 2019.

Dimıć, Ljubodrag, Kulturna politika Kraljevine Jugoslavije, 3 sveska, Beograd, 1996.

Duвbs, Chris, American Journalists in the Great War: Rewriting the Rules of Reporting, Lincoln, 2017.

Ferro, Marc, Resentment in History, Cambridge - Malden, 2010.

Friedjung, Heinrich, Geschichte in Gesprächen: 1904-1919, sv. 2, ur. Franz Adlgasser, Margret Friedrich, Wien, 1997.

Gross, Mirjana, Nacionalnointegracijske ideologije u Hrvata od kraja ilirizma do stvaranja Jugoslavije, u: Društveni razvoj u Hrvatskoj od 16. do početka 20. stoljeća, ur. Mirjana Gross, Zagreb, 1981., 283 - 306.

HAMERŠAK, Filip, Tamna strana Marsa: hrvatska autobiografija i Prvi svjetski rat, Zagreb, 2013.

HanÁ, Péter, The Garden and the Workshop, New York, 1998.

Healy, Maureen, Vienna and the Fall of the Habsburg Empire: Total War and Everyday Life in World War I, Cambridge, 2004.

Ignjatović, Aleksandar, Images of the Nation Foreseen: Ivan Meštrović's Vidovdan Temple and Primordial Yugoslavism, Slavic Review, sv. 73/4, Cambridge, 2014., 828-858.

Johnston, William M., Austrijski duh, Zagreb, 1993.

Johnston, William M., Der österreichische Mensch: Kulturgeschichte der Eigenart Österreichs, Wien, 2010.

KrašEvac, Irena, Ivan Meštrović i secesija. Beč-München-Prag 1900 - 1910, Zagreb, 2002.

KRAŠEVAC, Irena, Ivan Meštrović und sein Wiener Mäzen Karl Wittgenstein, u: Wechselwirkungen, sv. 7: Übergänge und Verflechtungen. Kulturelle Transfers in Europa, ur. Gregor Kokorz i Helga Mitterbauer, Bern, 2004., 129 - 145.

MaChiedo Mladinić, Norka, Prilog proučavanju djelovanja Ivana Meštrovića u Jugoslavenskom odboru, Časopis za suvremenu povijest, sv. 39/1, Zagreb, 2007., $133-156$. 
MARUŠEvs Ki, Olga, Društvo umjetnosti 1868.-1879.-1941., Zagreb, 2004.

May, Arthur, J. R. W. Seton-Watson and British Anti-Hapsburg Sentiment, American Slavic and East European Review, sv. 20, Cambridge, 1961., 40 - 54.

Pederin, Ivan, Stadler, Pilar i Jugoslavenski odbor u Londonu 1917./1918., Croatica Christiana periodica, sv. 29., Zagreb, 2005., 163 - 183.

Pijade, Moša, Ivan Meštrović i težnja za stilom u našoj umetnosti, Slobodna reč, sv. 40/41, Beograd, 1919., 1 - 16.

Plener, Peter, Reichel, Walter, "Extraausgabee -!": die Medien und das k.u.k. Kriegspressequartier, Wien, 2015.

Prelog, Petar, Artikulacija moderniteta. Institucije, secesije, publika, u: Moderna umjetnost u Hrvatskoj 1898.-1975., ur. Ljiljana Kolešnik, Petar Prelog, Zagreb: Institut za povijest umjetnosti, 2012., 10 - 39.

Schors Ke, Carl E., Beč krajem stoljeća, Zagreb, 1997.

SRHoJ, Vinko, Ivan Meštrović i politika kao prostor ahistorijskog idealizma, Ars Adriatica, sv. 4, Zadar, 2014., 369 - 384.

ŠImetin ŠEgvić, Filip, Patriotizam i bunt: Franjo Josip I. u Zagrebu, Zagreb, 2014.

TEPPERBERG, Christoph, »Wie eine idyllische Sommerfrische «- 》Dichtdienst « und »Heldenfrisieren«. Kriegspressequartier und Kriegsarchiv als Instrumente der k. u. k. Kriegspropaganda 1914-1918., u: Die Mittelmächte und der Erste Weltkrieg, ur. M. Christian Ortner, Hans-Hubertus Mack, Wien, 2016., 348 - 376.

Trogrlić, Marko, Šetić, Nevio, Dalmacija i Istra u 19. stoljeću, Zagreb, 1915.

Unows Ky, Daniel L., The Pomp and Politics of Patriotism: Imperial Celebrations in Habsburg Austria, 1848-1916, West Lafayette, 2005.

ÜBeregger, Oswald, Kulturelle Mobilisierung. Die österreichisch-ungarische Kriegspropaganda gegen Italien, u: Krieg in den Alpen: Österreich-Ungarn und Italien im Ersten Weltkrieg (1914-1918), ur. Nicola Labanca, Oswald Überegger, Wien, 2015., 259 - 280.

VuČETIĆ, Radina, Jugoslavenstvo u umjetnosti i kulturi - od zavodljivog mita do okrutne realnosti (Jugoslavenske izložbe 1904.-1940.), Časopis za suvremenu povijest, sv. 41/3, Zagreb, 2009., 701 - 714 .

Vugrinec, Petra, Hrvatski salon i bečka secesija: slikarstvo u Zagrebu i Beču oko 1900., u: Izazov moderne: Zagreb-Beć oko 1900. Slikarstvo, kiparstvo $i$ arhitektura zagrebačke $i$ bečke secesije, ur. Irena Kraševac, Petra Vugrinec, Zagreb, 2017., 57 - 124. 
Filip ŠIMETIN ŠEGVIĆ

\section{ART AS PROPAGANDA: IVAN MEŠTROVIĆ, CONFLICTING PARALLEL CULTURAL POLICIES AND THE GREAT WAR}

\section{SUMMARY}

This article is based on comparative history and cultural and intellectual history. It includes an analysis of the existing reference domestic and foreign literature, newspaper sources and archival sources of various kinds. The paper analyses the parallel cultural policies of Ivan Meštrović in Great Britain (19151918) within the Yugoslav Committee on the one hand and attempts to mobilize the civilian population in Croatia during the Great War through propaganda war exhibitions. The process explains the genesis of the split between artistic circles and the hostility between the regime's representatives (I. Kršnjavi). It also explains the ideological matrix of those who were supporters of cultural Yugoslavism. Therefore, the paper's introduction describes the situation from 1911 when a group of Croatian artists exhibited under the Serbian pavilion in Rome and a counter-exhibition organized in Zagreb. It also shows how the propaganda use of culture and art gradually led to theses reversals or subsequent ideological deepening of works of art. This was especially clear in the case of Meštrović's cultural tour of Great Britain, where he staged exhibitions in several large cities. We describe the activities of Croatian artists (O. Alexander, O. Iveković and R. Frangeš-Mihanović) within the Main Headquarters of the War Press as a central gathering place for intellectuals and artists from the entire Habsburg Monarchy. We also point out the propaganda strategy of that office as a form of cultural policy during the war. The failed initiatives and scandals handled by the Department of Religious Affairs and Education are also viewed as a place to create the cultural policy of the Government of Land. The paper presents different reactions, achievements, goals and attempts to assess the success of propaganda art events during the Great War. It also points out various controversies or personal conflicts that ensued from the atmosphere of the last war year.

Keywords: Great War, propaganda, culture, art, exhibitions, intellectuals, Ivan Meštrović, ideology. 